2013

\title{
Does the Military Train Men to be Violent Criminals? New Evidence from Australia's Conscription Lotteries
}

Peter Siminski

University of Wollongong

Simon Ville

Univesity of Wollongong

Alexander Paull

University of Wollongong

\section{Recommended Citation}

Siminski, Peter; Ville, Simon; and Paull, Alexander, Does the Military Train Men to be Violent Criminals? New Evidence from Australia's Conscription Lotteries, Department of Economics, University of Wollongong, Working Paper 13-01, $2013,39$.

http://ro.uow.edu.au/commwkpapers/331

Research Online is the open access institutional repository for the University of Wollongong. For further information contact the UOW Library: research-pubs@uow.edu.au 
UNIVERSITY OF

WOLLONGONG

FACULTY OF COMMERCE

\title{
Economics Working Paper Series 2013
}

http://www.uow.edu.au/commerce/econ/wpapers.html

Does the Military Train Men to be Violent Criminals? New Evidence from Australia's Conscription Lotteries

\author{
Peter Siminski \\ School of Economics \\ University of Wollongong and IZA \\ Email : siminski@uow.edu.au \\ Simon Ville \\ School of Economics \\ University of Wollongong \\ Email : sville@uow.edu.au \\ And \\ Alexander Paull \\ School of Economics \\ University of Wollongong
}

WP $13-01$

January 2013 


\title{
Does the Military Train Men to be Violent Criminals? N ew Evidence from Australia's Conscription Lotteries*
}

\author{
Peter Siminski, University of Wollongong \& IZA \\ Simon Ville, University of Wollongong \\ Alexander Paull, University of Wollongong
}

$15^{\text {th }}$ January, 2013

\begin{abstract}
Combat is the most intense form of military service, but several aspects of the training experience, which explicitly prepares people for violent warfare, are hypothesized to link service to violent crime. Using Australia's Vietnam-era conscription lotteries for identification and criminal court data from Australia's three largest states, we seek to estimate the effect of army training on violent crime. Using various specifications, we find no evidence that military training causes violent crime, and our point estimates are always negative. In our preferred specification (using only non-deployed cohorts), we rule out with 95\% confidence any positive violent crime effects larger than $3.6 \%$ relative to the mean.
\end{abstract}

JEL Codes: H56; I12; J45

Keywords: Violent Crime; Military Service; Natural Experiment; A ustralia

\footnotetext{
* We are grateful to Joshua Angrist, William N. Evans, Jason Lindo, Alfredo Paloyo, Joan R. Rodgers and seminar participants at the Melbourne Institute of Applied Economic and Social Research, the University of Technology Sydney and the University of Tasmania for discussions and comments on preliminary work. We thank Daniel Thomason for excellent research assistance. For criminal court data we are grateful to NSW BOCSAR, the Queensland Department of Justice and Attorney-General, and the Victorian Department of Justice. We acknowledge grant support from the Australian Research Council (LP100100417 and DE120101642) and the Department of Veterans' Affairs. The views expressed in this paper are the authors' alone, as are any errors of fact or omission.
} 


\section{Introduction}

In recent years, economists have contributed to an interdisciplinary consensus on the central role of early life experiences in determining life outcomes (Knudsen et al. 2006). ${ }^{1}$ While other disciplines have studied the importance of early childhood for many decades, the recent contributions of economists can be distinguished by their application of quasi-experimental identification strategies. This growing evidence base has been accompanied by calls for public policies to focus increasingly on early childhood interventions.

Nevertheless, people still may be malleable, or vulnerable to significant life events, in early adulthood. Yet the extent to which intense psychological experiences shape young adults' lives has rarely been studied by economists. One appealing context in which to address this void is military service, which is undertaken globally by a significant fraction of young males. A number of studies have explored the effect of military service on wages and employment. ${ }^{2}$ Their results must be interpreted in light of numerous potential mechanisms involved, including how valued military service is in civilian labor markets (Angrist 1990), what impact veterans' programs have on human capital (Angrist 1993; Bound and Turner 2002), and what direct and incentive effects veterans' disability compensation has on those who served (Autor et al. 2011; Siminski forthcoming). An additional complication for studying conscripts (who did not choose military service) is that any negative economic effects may reflect their comparative advantage in the civilian labor market (Keane 2010; Oi 1967).

Thus, for a variety of reasons, effects on eamings and employment do not speak directly to our primary interest: whether the military experience is harmful for psychological or social

\footnotetext{
${ }^{1}$ A number of studies have found large effects of in utero shocks to maternal nutrition, disease and pollution on adult health outcomes, educational attainment and wages (Almond and Currie 2011a). Children's characteristics, measured at an early age (5 or 7 years) explain a large fraction of variation in adult economic outcomes (Almond and Currie 2011b). Recently, Currie and Tekin (2012) showed that maltreatment in childhood greatly increases victims' probability of subsequently perpetrating crime.

${ }^{2}$ Examples include studies for the United States (Angrist 1990; Angrist and Krueger 1994; Angrist 1998; Angrist et al. 2011; Angrist and Chen 2011), the Netherlands (Imbens and van der Klaauw 1995), Germany (Bauer et al. 2012; A. Paloyo 2010), Britain (Grenet et al. 2011), Portugal (Card and Cardoso 2012) and Australia (Siminski and Ville 2012; Siminski forthcoming).
} 
functioning. Previous studies using direct measures of mental health have suffered from limitations in statistical power (Dobkin and Shabani 2009), and because of the complications inherent in interpreting clinically diagnosed and self-reported health outcomes for veterans (Siminski and Ville 2012). An alternate approach is to study behaviors that may be indicative of such problems. To that end, several papers have studied mortality, focusing especially on external causes, such as suicide and motor vehicle accidents (Angrist et al. 1996; Conley and Heerwig 2012; Hearst et al. 1986; Siminski and Ville 2011). Overall, they do not find strong evidence of elevated mortality; however, death is a rare and extreme event among the relatively young populations included in these studies.

The perpetration of violent crime is another relevant outcome, one far more common than death, among young males. Military service has been hypothesized to increase tendencies for violence through several mechanisms, including removal from familiar social environments, indoctrination into masculine military culture, familiarization with weapons, the experience of extreme stress, and exposure to and participation in violent combat. Three recent studies have investigated the effects of military service on crime, each adopting credible identification strategies (Galiani et al. 2011; Lindo and Stoecker forthcoming; Rohlfs 2010). These studies appear to present a consensus, because each finds some evidence of positive effects of military service on crime perpetration.

However, we argue that the effect of military training on violence remains an open question. Rohlfs (2010) explicitly focused on combat intensity. Combat might also be the mechanism driving Lindo \& Stoeker's (forthcoming) results. ${ }^{3}$ Combat is certainly a more intense experience than military training, and thus one may expect to find greater effects of combat exposure on outcomes such as mental health and violence. Nevertheless, as we will discuss later in detail, several of the hypothesized mechanisms linking military service to violent crime relate specifically to the training experience. Further, combat events are relatively rare, even among military personnel, let alone among civilians. It is difficult to find good data on the numbers of service people exposed to combat, but they are likely dwarfed by the numbers who receive

${ }^{3}$ Exploiting between-cohort variation, Rohlfs (2010) finds an effect of combat intensity on violence among Vietnam veterans. Using conscription lottery IV identification, Lindo \& Stoeker (forthcoming) find an effect of Vietnam-era service (which for some included combat) on violent crime. While the estimates from both studies are imprecise, taken together they suggest combat exposure may lead to violent crime perpetration. Clearly such a link is of major policy relevance. 
military training. ${ }^{4}$ Finally, training is probably a more homogeneous treatment to study than deployment or actual combat.

Only one previous paper has used a quasi-experimental methodology to study the effects of nondeployed military service on crime: Galiani et al. (2011) studied the case of Argentina, using conscription lottery identification. ${ }^{5}$ They find evidence of significant, but small effects on overall crime, but their estimates for vident crime are not statistically significant. Instead, they find significant effects on property crimes, which they argue may reflect the reduced economic opportunities faced by conscripts. These results highlight the importance of providing veterans with adequate training and support for re-engagement with civilian labor markets. Nevertheless, a link between army training and violence has not been established.

We contribute to this evidence base, using the exogenous variation provided by Australia's Vietnam-era conscription lotteries. Between 1965 and 1972, 15 biannual birth cohorts were subjected to conscription lotteries, conducted by date of birth, although no one from the last three of these cohorts was deployed (Ville and Siminski 2011). ${ }^{6}$ We draw on a near universe of criminal cases with male defendants of relevant age heard in a 17-year period (1994-2010) in New South Wales (NSW), Victoria (VIC) and Queensland (Q LD), representing nearly 500,000 alleged criminal offenses. ${ }^{7}$ These three states constitute over three quarters of the Australian population. Using three alternate specifications, we consistently find no evidence that army training causes violent crime, and our point estimates are always negative. In our preferred specification (using only non-deployed cohorts), we can rule out with $95 \%$ confidence any positive crime effects larger than $3.6 \%$ relative to the mean rate.

${ }^{4}$ In 2012, there were approximately 20.3 million individuals globally serving in permanent military forces, another 44.9 million reservists, and 7.9 million paramilitary personnel (International Institute for Strategic Studies 2012). However, deployment is not a good proxy for combat exposure. By comparison, there were 0.6 million service-people deployed outside of their national borders in November 2011 (over half of whom were from the US). In the Vietnam War era, less than 1 in 3 Australian conscripts were deployed, while $5 \%$ of those who did serve in Vietnam were wounded (Wilson et al. 2005).

${ }^{5}$ See also Paloyo $\&$ al. (2010) for an analysis of the effect of military bases on local crime rates.

${ }^{6}$ A $16^{\text {th }}$ birth cohort also was subjected to a National Service lottery in September 1972. However, the conscription system was abolished before they were due to be called up. Thus we ignore the $16^{\text {th }}$ cohort.

${ }^{7}$ Earlier data are not available. 
We also aim to make clear the nature of the 'treatment' - i.e., to document the nature of Australian army training in this era, which may differ from that of other countries. By doing so, and by focusing on non-deployed service, we can be relatively explicit about the mechanisms we test. Overall, our results do not suggest that military training induces violent behavior in civilian life, at least not in the long run.

The remainder of the paper is organized as follows. Section 2 outlines the potential mechanisms linking military training to violent crime, as proposed in the psychiatric literature. Section 3 describes the context of National Service in Australia, focusing on men who were not deployed. Sections 4 and 5 outline methods and data respectively. The results are presented in Section 6, and Section 7 concludes.

\section{The Mechanisms Linking Military Training to Violent Crime}

Several potential mechanisms causally link military training to violent crime. These mechanisms, overlapping to some degree, derive from the recruit's disconnection from a normal social environment, from the set of beliefs or value system inculcated by the military, and from the inherent nature of the training itself.

Military training centers, or 'camps', remove individuals from their 'normal' diverse social and geographic environment. Recruits are moved to a single place, often rather geographically remote, along with a fairly similar group of people, under the aegis of a single powerful organization. Thus there is a sense of dislocation from a heterogeneous, open and familiar environment to socialization into a new, homogenous, unfamiliar, and closely controlled one. Such circumstances are not unique to military recruits. They may be found among religious, political, or corporate groups keen to socialize their members into a specific set of values and forms of behavior. In some respects, this might be considered a form of indoctrination.

The environmental context of service training thus provides a fertile setting for instilling a particular culture. This is reinforced by explicitly setting out expectations about behavior in the camp and enforcing them through the use of a powerful system of incentives that reward conformity and punish deviance (Roberts et al. 2008). It has been argued persuasively in the literature that military training fosters a distinctive set of values. Arkin \& D obrofsky (1978: 166) suggest that the physical isolation and community insulation help to shape behavior toward a philosophy of 'militarization' among recruits: 'The purpose of basic training is to militarize, which means to give a military character or to adapt for military use.' Training to become 
proficient in weapon handling and use, they argue, comes later. They unpack the term militarization to some degree by explaining it as 'socialization into a masculine domain'. Aspects of masculinity, including the role of aggression and dominance in combat situations, have been equated positively with military performance as justification for this socialization (Eisenhart 1975; Nicol et al. 2007).

A recent study of $\mathrm{G}$ erman recruits provides a rare examination of the effect of military training on personality, arguing that the experience led to permanently muted levels of 'agreeableness' (Jackson et al. 2012). It is not clear, though, whether that was the intended result of militarization or simply the consequence of withdrawal from normal civilian life. 'Agreeableness' - one of the 'big five' personality traits - has been inversely correlated with aggressive behavior because individuals with low levels of agreeableness tend to act in a manner that is anti-social, disengaged, and lacking empathy (Graziano et al. 1996; Graziano et al. 2007; Miller and Lynam 2001; Wilkowski et al. 2006). They also lack the cognitive processes to mitigate tension in interpersonal relations, and they expect hostile reactions from others (Anderson and Bushman 2002; Wilkowski et al. 2006). Lack of agreeableness has been associated with various life outcomes, including negative experiences in romantic relationships, diminished performance and interpersonal conflict in team-based work environments, lack of community involvement, and higher rates of criminality (Mount et al. 2006; Ozer and Benet-Martinez 2006). However, such lack of agreeableness might be considered a desirable feature of military training, because it enables the recruit to respond rapidly and aggressively to hostile situations.

These 'desired' military traits, though, may also be relevant for violent behavior outside the military. Links between them and heightened levels of violence in general have been described in the literature. For example, masculinity has been identified with sexual violence (Morris 1996); dominance with violence against minority groups (Houdepohl et al. 2010); and low agreeableness with violent rather than conciliatory responses to interpersonal conflict (Martin et al. 2000; Wilkowski et al. 2006). Some authors have gone so far as to suggest that part of the indoctrination of military values included violence. Eisenhart (1975), for example, implies that systematic acts of violence were committed as part of the process of militarization.

A further potential mechanism that links military training to violence is related to 'strain theory': the idea that being treated in a negative or aversive manner may lead to delinquent, particularly aggressive, behavior (Agnew 1992). Not all recruits are easily 'militarized' because of their personality or belief systems, but resisting militarization may have led to strain. So, two of 
Agnew's three categories of strain appear to be relevant: failure to achieve valued goals and negative stimuli.

However, it is also possible that militarization fosters other, countervailing, personality traits that more positively affect life outcomes. These might include teamwork, respect for authority, selfdiscipline, and the development of a broader skill set. So, for example, although a lack of agreeableness is related to anti-social behavior, teamwork may serve as an antidote to that. And, self-discipline may discourage hostile and aggressive behavior. In a study of World War Two and the Korean War, Elder and Clipp (1989) found that 54 percent of non-combat veterans reported improved self-discipline and 53 percent learned cooperation as a consequence of their military experience. Sampson and Laub (1996) have argued for the benefits of in-service education and training among socioeconomically disadvantaged men. More broadly, accelerated maturity brought on by military service can help to reduce the propensity for violent behavior, particularly as traits such as agreeableness strengthen with age. Publicity for military recruitment regularly talks about its accelerating effect on individual maturity, and training future leaders to be prepared to meet challenges (http:// www.defencejobs.gov.au/; http:// www.goarmy.com/). Elder (1988) discusses the enhanced developmental processes that result from military service.

The training regime itself forms part of the militarization process for the recruit and can have a major bearing on the development of behavioral traits, particularly where they relate to the psychological preparedness for combat. Strategists in most wars have expressed concern about the willingness of servicemen to kill the enemy, either because of moral objection or through a sense of fear brought on by the shock of combat engagement. G rossman has argued that several training techniques developed by the US Army around the time of the Vietnam War were designed to desensitize troops to the trauma of killing (Grossman 1995: 249-61). For example, sudden rapid shooting ('Quick Kill') involves the soldier being trained to react spontaneously and intuitively without time to reflect on the act of killing. Providing greater realism through human-shaped shooting ranges and moving targets ('Trainfire') acclimatizes recruits to the experience of killing. By desensitizing soldiers to the violence of killing, these new techniques while designed to improve operational efficiency in combat - risk breeding soldiers inured to committing violent crimes outside the military. Grossman's hypothesis is predicated on earlier calculations by Marshall (1978) that firing rates rose dramatically during Vietnam: almost all American combat servicemen fired their weapons, compared with only 15 to 25 percent in World War Two. 
However, Marshall's view of World War Two has been variously criticized for both its methodology and observationally by war participants (Glenn 2000: 3, 30). Glenn (2000: 69-71) also provides evidence of training regimes in earlier wars that exposed recruits to similar realism scenarios; he suggests that Canada may have been the pioneer in the use of live firing half a century earlier, during World War O ne. The extent of adoption of desensitizing regimes by other nations has varied across time and place. For example, the superior performance of the British troops against the Argentinean army in 1982 during the Falklands War has been attributed to their earlier use of such techniques (G rossman 1995: 257-8).

All nations' military training regimes require recruits to develop very high levels of physical fitness and to become proficient in handling an array of weapons, although the precise nature and accomplishments will vary. It could be argued that these skills, if very well-honed, remove practical barriers to perpetrating certain types of violent crimes, particularly where firearms are used for the attack (Galiani et al. 2011:120). However, even in countries where firearms are readily available, only someone psychologically inclined to resort to violence is likely to exploit this proficiency. Moreover, such proficiency is not required to commit most acts of violence.

To summarize, we have identified two sets of literature: one which intimates that military training may cause shifts in personality traits and belief systems; another that associates those acquired qualities with violent behavior. Nevertheless, the magnitude of such effects is not clear, and a direct link between military training and civilian crime has not been established. There may also be offsetting positive experiences from military training, as suggested above. And there are questions about how permanent any training-induced personality shifts are, and whether such behavior translates to life beyond the military. The post-mobilization influence of training is most likely to wane if recruits effectively distinguish between the context of their role as a soldier in the military and their place in civilian society. The training experience of the modern soldier might be viewed as preparation for a profession, with its own set of values and experiences unique to that role, and which the recruit can separate from civilian life. Age at enlistment, the length and precise nature of training, and whether recruitment is voluntary or by conscription all may bear on the behavioral impact. Younger, less mature recruits may be more susceptible to changes in personality traits. The impact also may be greater with longer continuous service. And, as we saw above, the specific nature of the training matters. Conscripts trained for a limited period of time compared with the volunteer recruits, but their enforced entry into the military may have contributed to a more serious effect on personality. 
In the following section, we investigate those mechanisms empirically through an examination of the nature of military training in the Australian army during the Vietnam period.

\section{National Service in Australia}

The Australian conscription ballots resulted in the enlistment of 63,735 National Servicemen ('Nashos'), after allowing for a range of exemptions and deferments. They all began their two years of service in the regular army with a period of training in Australia. After this, 18,654 (29 percent) of them spent part of their service, typically one year, in Vietnam; the rest mainly served their time in Australia. All Nashos subsequently completed three years in the reserves in Australia. In this section, we analyze the nature of the training that all Australian recruits received, and compare it to the American experience, to learn about the possible relationship between military training and behavioral traits associated with heightened levels of violence.

Training occurred in three stages: ten weeks of general recruit training, followed by three months with a particular Corps, and finally a similar period training with the assigned unit. The initial stage targeted high levels of physical fitness and some general military skills. The Corps training focused on learning the particular functional skills and operational requirements of a Corps member, whether infantry, tanks, engineering, or artillery. For those units destined for Vietnam, there was further specialized training at the Jungle Training Centre at Canundra (QLD) and through participation in group test exercises at Shoalwater Bay (QLD) (Fett et al. 1984; Ham 2007; O 'Brien 1995). This was similar in length and nature to American training for Vietnam, which consisted of eight weeks of 'basic' training, nine weeks of 'advanced individual training' by function, and up to three months of training with the unit (Glenn 2000: 52-5).

Nashos trained full time in military camps where they were separated from their customary social and geographic environment. This was part of a strategy of immersion in a new social structure, to acclimatize recruits to the way of military life. The three recruit training camps - at Kapooka (NSW), Singleton (NSW), and Puckapunyal (VIC) - were located outside major population centers. Leave was granted fairly infrequently, and only after five weeks of the program. Nonetheless, the extent of isolation should not be exaggerated. Travelling to nearby towns was relatively straightforward and leisure activities, such as trout fishing, were available in scenic areas close to the camps (O 'Brien 1995: 8). Camp visitors were allowed on particular dates, as were some phone calls after three weeks; and, many recruits wrote regularly to family and friends (Q uigley unpublished). 
Contact with the outside world was most constrained during recruitment training, because this was the main period in which the army sought to modify attitudes and behavior, the so-called 'militarization' of recruits. Their memoirs describe intense hard work, overlain with the endless voice of corporals and sergeant majors shouting verbal abuse ('hazing'), including sexual innuendo and sometimes xenophobic language. The recruits learned to conform strictly so as to avoid demeaning individual or group punishments and chores that only added to their workload. Ray Andrews wrote to his family from Puckapunyal: 'I've worked 42 hours out of the last 55, and I start at 5.00 am tomorrow for a 14-hour shift - Whacko!' and later: 'I hate this rotten hole' (D onnelly 2001: 202, 203). Brian Hennessy similarly noted: 'Most nights saw us collapse exhausted onto our bunks' (Hennessy 1997: 9). In addition to the physical exhaustion, they believed the training was designed to mitigate their sense of individualism (Rintoul 1987: 19).

Although there was much in the atmosphere and life of the camps that recruits found unpleasant and stressful, most of them learned to cope with these demands. Friendship, humour, and sometimes disdain helped them to deal with the verbal onslaughts. They adapted and, at the end, some believed it had been a maturing process and felt pride at emerging as a professional soldier (Hennessy 1997: 3). While this environment clearly bred a sense of masculinity, physical assertiveness in military tasks, and self-confidence, it is less obvious that it translated into general aggression outside of the military and in a desire to be dominant and less agreeable. Certain positive aspects to the training, as we hypothesized in Section 2, may have offset some of these more egregious characterizations, including: building self-discipline, leadership, friendship, camaraderie, and team work (D onnelly 2001: xi, 94; Ham 2007: 174; Rintoul 1987: 13). Both teamwork and strong character were explicitly mentioned among the goals of training (Training Information Report unpublished-a: 29 April 1970). Since most Nashos were put into the infantry corps to help boost its numbers rapidly, many groups of recruits who had built up teamwork through their initial training remained together.

American recruits encountered a comparable training regime, particularly the 'shock, separation and disorientation' of 'boot' camp, the masculine environment, and the surrender of individuality' (Ebert 1993: 25-8). Their training syllabi, and the evidence of officers, paints a similar picture of confidence building and teamwork as highly valued attributes (Glenn 2000: 39, 53). However, there were differences in the training regimes of the two nations. McNeill (1984: 195) believes that the American training was designed to prepare troops for expected large-scale battles with the invading North Vietnamese, which motivated more aggressive forms of training (Ebert 1993: 46-8). Norman Simpson, who served for Australia in Korea, Malaya, and Vietnam appears to confirm these differences in attitude during his conversation with an American 
soldier: "He said that most Americans believed in the "Wild West" syndrome. The gun is supreme. That, I now believe, is the background mentality of the American Army' (Simpson unpublished: 27).

D rawing upon their experiences in Malaya in the 1950s, Australians trained for a war of less overt aggression and more counter-insurgency stealth, requiring careful marksmanship, jungle patrols, and occasional ambushes (McNeill 1984: 195). This necessitated small units surviving in a harsh tropical climate and conducting a covert, searching strategy that rarely involved significant contact with the enemy. It also emphasized minor engineering skills, such as using winches, searching for tunnels, and maintaining functioning weapons in humid conditions (ATF Lessons learnt). America's decision not to train for counter-insurgency until well into the Vietnam War has been studied (Longley 2008: 67; Westheider 2007: 61).

As the war developed, pacification skills - working in close contact with the Vietnamese civilian population - also were needed, along with the deployment of trade skills to help rebuild damaged community infrastructure (Exercise Unison). Australian training syllabi included languages and culture and provided advice on relations with the Vietnamese people: 'troops must not only be trained to operate effectively against their enemies in the field, they must also be taught to play their part correctly in .... the campaign to win the support of the people. ..., a willingness to co-operate, to share resources with civilian agencies and to behave sympathetically towards the people of the country.' ('Q uelling Insurgency'). In the American training there appears to have been only limited attempts to understand Vietnamese society and culture (Ebert 1993: 49-53; Westheider 2007: 51-2).

While recruit training shaped overall attitudes and behavior, the Corps stage focused on development of specific skills. To become a professional soldier, the recruits were expected to achieve proficiency in driving, navigation, communication, simple engineering, and first aid, along with a set of specific Corps functions (D ucker Papers). Most of the skills were designed to support the servicemen in combat, but they competed for time with training that was more directly related to battle, such as weapons handling and marksmanship. Thus, a relatively limited amount of time was dedicated to activities that were more likely to promote traits such as aggression, dominance, and lack of agreeableness.

In Section 2 we saw that two new techniques introduced by the American army have been associated with desensitizing servicemen to the act of killing (Grossman 1995). In Australia Trainfire was introduced in 1958 to improve target practice, but by 1966 there were concerns about its effectiveness. The discussion was not about whether it managed to personify the enemy 
and thus contribute to the realism of killing, but rather its operational inflexibility: it focused on firing at a 25-meter range target, whereas target detection, close-quarter firing practice, and firing during assault all were considered to be more important (Training Information Bulletin 13 1966: 4). The Americans introduced Quick Kill in 1967 as a form of spontaneous and aggressive shooting (Ebert 1993: 54) and during Vietnam training, techniques and tactics regularly were shared between the allies, either through joint exercises, joint seminars, or circulation of the US Training Information Bulletins. However, the Americans' training practices were not accepted uncritically. The Military Board in Australia in 1968 trialled and discussed whether to adopt 'Q uick Kill', but by August 1969 it had decided that, 'the US Q uick Kill method of rifle shooting will not be adopted in Australia' (21 August 1969 letter). Accurate marksmanship in a variety of situations was viewed as more important than continuous shooting. In Australia there were concerns about the appropriateness of Quick Kill for the conflict in Vietnam: 'Q uick Kill ... is often difficult to use in Phuoc Tuy province where it is necessary to apply Rules of Engagement and therefore make a positive identification or at least discount the possibility of friendly troops/ innocent civilians before engaging or movement' (Training Information Report unpublished-b: 8.11.70). Although the American Army trained using Quick Kill techniques, it was also conscious of the sacrifice of accuracy that it involved (Glenn 2000: 68).

Australian personnel in Vietnam alluded in their reports to concerns that newly-arrived recruits were wary or even frightened of live ammunition, grenades, or mines. So-called 'peacetime restrictions' meant that live fire could not be used near recruits in training scenarios. These issues were noted in 1966, and were still being discussed as late as 1971 when it was observed: 'Live artillery firing cannot be conducted anywhere near our own troops...so restrictive as to lose all realism. It is accepted that a 'safety first' policy will always apply to training in Australia, but safety regulations should be flexible enough to allow more realistic conditions' (Training Information Report unpublished-b: 27.7.1971). Thus, while some troops who served in Vietnam would have encountered combat situations with live fire, the majority who remained in Australia were not exposed to the realism, or even to an effective simulation, of live fire at close quarters which might have inured them to acts of violence. In contrast, although it had been suspended between 1945 and 1950, American infantry training included live firing in the vicinity of recruits by the time of Vietnam. However, it appears to have been directed well away from troops and the general experience fell far short of a realistic battle environment (Glenn 2000: 74). Ebert (1993: 149) summarizes that recruits were 'rarely prepared for the confusion and noise, the chaos and disorder, or the death and suffering encountered in battle.' 


\section{Methods}

The empirical approach that we adopt exploits the randomness of the conscription lotteries. It is similar to recent Australian research (Siminski and Ville 2011, 2012; Siminski forthcoming), which in turn is based on related US work (some examples are Angrist 1990; Lindo and Stoecker forthcoming and many others).

O ur primary aim is to estimate the effect of army training (not deployment, or combat) on various measures of individual crime perpetration, especially violent crime. Crime perpetration (y) by person $\mathrm{i}$ in birth cohort $\mathrm{j}$ is expressed in equation (1) as a linear function of army training $(r)$, birth cohort fixed-effects $(\alpha)$ and other individual-level determinants of crime perpetration $(\mu)$.

$y_{i j}=\beta r_{i j}+\alpha_{j}+\mu_{i j}$

$\beta$ is the causal parameter of interest. If army service had been randomly assigned within birth cohorts, OLS estimation of (1) would yield unbiased estimates of $\beta$. Despite the conscription lotteries, army service was not randomly assigned. In particular, many potential conscripts were screened-out in the medical examination, while many 'balloted-out' men joined the army voluntarily. Therefore, $\mathrm{r}$ is almost certainly correlated with $\mu$ and OLS estimation of (1) would likely yield biased and inconsistent estimates of $\beta$.

Adding control variables is not a satisfactory solution, because some determinants of crime perpetration are inevitably unobservable. Instead, we use 2SLS. The (binary) conscription lottery ballot outcome ( $\mathrm{z}$ ) is a randomly assigned source of variation in the probability of army service. $\mathrm{z}$ could be used as a single instrument for army service in a just-identified first-stage regression. Instead, we allow the effect ( $\pi$ ) of the ballot outcome to vary between birth cohorts:

$r_{i j}=\pi_{j} z_{i j}+\gamma_{j}+\varepsilon_{i j}$

Equations (1) and (2) specify an over-identified 2SLS model, where $\pi_{j}$ is the (first-stage) effect of ballot outcome on the probability of army enlistment for men in birth cohort $j$. This approach 
yields more precise estimates than the just-identified alternative, because the effect of the ballot outcome on the probability of being enlisted in the army varies between cohorts. ${ }^{8}$

In our preferred analysis, we restrict the sample to the three youngest cohorts (men born between January 1951 and June 1952), because conscripts from these cohorts were not deployed to Vietnam, or to any other combat area.

Then we repeat the analysis using the same specification, with the sample extended to the full set of 15 birth cohorts (men born between January 1945 and June 1952.) We interpret these estimates as upper bounds on the effect of army training on the assumption that deployment to Vietnam did not reduresubsequent crime perpetration, on average. ${ }^{9}$

We also produce a third set of estimates, again using all 15 cohorts, in a specification that separately identifies the effect ( $\beta_{\mathrm{r}}$ ) of army training and the additional effect ( $\left.\beta_{\mathrm{r}}\right)$ of deployment to Vietnam (v). Here, the substantive equation is:

$y_{i j}=\beta_{r} r_{i j}+\beta_{v} v_{i j}+\alpha_{j}+\mu_{i j}$

where rand vare both endogenous and both instrumented by the same set of 15 IVs (the ballot outcome in each cohort). This strategy relies on the fact that the probability of deployment varied considerably between cohorts of conscripts.

In each specification, individual-level data needed to estimate the second-stage regression are not available. However, a group-means approach yields identical point estimates to that of individual data, as well as consistently estimated standard errors (Angrist 1991; Angrist and Pischke 2009). Here, each group is an exact DOB. For example, the 2SLS estimates that correspond to the specification in equation (1) are obtained by GLS estimation of:

$\bar{y}_{d j}=\beta \bar{r}_{z j}+\alpha_{j}+\mu_{d j}$

\footnotetext{
${ }^{8}$ Using just-identified models, the standard errors of the key estimates are approximately $1 \%$ (5\%) larger for the 3-cohort (15-cohort) specification. Results from just-identified models are qualitatively similar, and are shown as a robustness test.

${ }^{9}$ This assumption is supported by positive point-estimates of the effect of deployment in almost all of the models where deployment is explicitly considered. These results are shown in Section 6.
} 
Each observation in (4) is an exact D OB, denoted by the subscript $d \bar{y}_{d j}$ is the mean number of crimes committed by men with a given DOB; and $\bar{r}_{z j}$ is the proportion of men who served in the army, by ballot outcome and birth cohort. In other words, $\bar{r}_{z j}$ is the predicted value from (2). The GLS weights are equal to the number of men with each D OB. Robust standard errors are shown in the results for each specification.

Each of the three versions of the analysis has pros and cons. When restricted to the youngest three cohorts, the analysis provides the cleanest estimates of army training, and thus is preferred. Estimates from the second specification, which uses all 15 cohorts and does not include v, are more precise but may be biased upwards. The third specification avoids this limitation, as well as yielding more precise estimates than the version restricted to younger cohorts. However, it assumes that among army service compliers, between-cohort differences in the probability of deployment are the only explanation for corresponding cohort differences in the effect of army service. While this is a plausible assumption, it is not as clean as restricting the sample to nondeployed cohorts. Ultimately, the strongest results are those that are consistent across each of the three versions of the analysis.

\section{Data Construction}

The first-stage individual-level database contains the universe of men in the relevant birth cohorts who were in Australia at age 20. It has been described in detail in Siminski (forthcoming). It was constructed from military personnel records and official population estimates from the 1960s and 1970s. Because recent migrants cannot be excluded from the second-stage (crime) database, the first-stage data also include synthesized records for migrants who arrived in Australia after the age of 20, in proportion to their fraction of each age cohort in 2006 (as recorded in Census data). This is for consistency with the second-stage data, and is the same approach used in Siminski (forthcoming) and (Siminski and Ville 2012) whenever recent migrants are not identifiable, and hence cannot be excluded from the second-stage data.

To construct the second-stage database, we draw on administrative data from criminal court cases heard during 1994-2010 in New South Wales, Victoria, and Queensland. These are the three largest Australian states and contain over $77 \%$ of the Australian population. During those years, the study population was middle-aged (41-65 years). Although crime rates for this age group are lower than for younger males, the data still include a substantial number of crimes. As 
shown in Table 1, they include 496,107 criminal offenses with male defendants bom between January 1945 and June 1952, of which 344,477 received guilty verdicts. In our preferred specifications, the offenses are grouped into cases, of which there are 164,211 with at least one guilty verdict. ${ }^{10}$ One-fifth of these cases are violent crimes; around one quarter are for drunk driving; and $13 \%$ were property crimes. ${ }^{11}$ Some 7,748 cases (5\%) resulted in imprisonment, most of which were non-violent cases.

With some exceptions, these data contain the universe of offenses heard by criminal courts in these states over this period. However, the coverage window begins in mid-1994 for Q ueensland and in 1995 for Victoria. Further, the QLD data prior to 2001 do not include cases heard in provincial courts. There is no reason to suspect that such missing data would disproportionately affect balloted-in or balloted-out men, thus introducing bias. And in any case, the results are not sensitive to the exclusion of pre-2001 QLD data, or indeed to the exclusion of QLD overall. Figure 1, which shows frequency counts of cases with at least one guilty offense by state and year, illustrates the likely extent of missing pre-2001 data in QLD. It also shows a general downward trend for each state, consistent with the aging of the study population.

We combine the crime data with counts of men living in NSW, QLD, and VIC combined, by exact D OB as recorded in the 2006 Census. For each D OB, we construct a set of outcome variables equal to the ratio of various crime counts to men. Across DOBs, the mean ratio of (guilty) criminal cases to men living in these states is 0.26 , as illustrated in more detail in the next section.

${ }^{10} \mathrm{~A}$ case is a set of one or more offenses heard on the same date for the same defendant. The results are not sensitive to analyzing offenses rather than cases, but are less precise due to a highly skewed distribution of the number of offenses within cases.

${ }^{11}$ Offenses are classified under the 2008 Australian Standard Offense Classification (ASOC) (ABS 2008). Violent offenses are those with a 4-digit ASOC code below 0630. This includes homicide and related offenses; acts intended to cause injury; sexual assault and related offenses; dangerous or negligent acts endangering persons; abduction, harassment and other offenses against the person; robbery, extortion and related offenses. Non-violent offenses are all other offenses. D runk driving offenses are those where the ASOC code is 1431. Property offenses are those with 4-digit ASOC codes ranging from 0600 to 1030. This includes robbery, extortion and related offenses; unlawful entry with intent/ burglary, break and enter; theft and related offenses; fraud, deception and related offenses; and illicit drug offenses (excluding possession, use or miscellaneous drug offenses). 


\section{Results}

\subsection{First-stage Results}

First-stage results are shown in Table 2. The upper panel reports estimates from the preferred specification, which is restricted to the youngest three birth cohorts and has only one endogenous variable (army service). The lower panel shows first-stage results for the full sample, drawn from all fifteen 6-month birth cohorts. In each case, the ballot outcome effect is allowed to vary between birth cohorts; therefore the models are over-identified.

The coefficients on the instruments are smaller than those previously reported (for example in Siminski forthcoming), which reflects the inclusion of recent migrants in the data here. Nevertheless, the ballot outcome is a strong predictor of army service for each birth cohort, inducing between 10 and 25 percent of this sample of balloted-in men into the army. For all but the youngest three cohorts, the ballot outcome is also a strong predictor of deployment to Vietnam.

In each regression, the first-stage relationships are very strong, as shown by the various firststage F-statistics reported, all of which exceed 900.

\subsection{Visual Presentation of Reduced-Form Results}

Figure 2 is a detailed graphical summary of the reduced-form relationship between ballotoutcome and crime, similar to Lindo \& Stoecker (2012). Much of the intuition of the results, including the precision of the estimates, is conveyed through these nine graphs. Each shows the ratio of crimes to population, by birth cohort and ballot outcome. In each graph, there is an upward trend from left to right, probably because the data availability window covers a different age range for each cohort. For example, the data include crimes at approximately ages 49-66 for the oldest cohort (shown on the left side of each graph), and for ages 41-58 for the youngest cohort.

Panel A shows the crime-to-population ratios for all criminal cases with a guilty verdict. Within each cohort, the difference between balloted-in and balloted-out DOBs is small and is sometimes positive, but often negative. This suggests that any effects of army service on overall crime likely will be small, but precisely estimated. Similar patterns are shown in each of the nine figures, which differ primarily in their extent of variation, likely reflecting the volume of crimes in each category. For example, the last four graphs show results for crimes resulting in imprisonment, derived from relatively few cases (as shown in Table 1). 


\subsection{SLS estimates}

The 2SLS estimates are presented in Tables 3, 4 and 5, one table for each of the specifications described in Section 4. Each table shows estimates from nine separate 2SLS models, each for a distinct category of crime rates as the dependent variable. The mean of each dependent variable is shown, along with estimated army service coefficients and their robust standard errors. However, the two columns on the right side are of primary interest. The second from right columns express the point estimates as percentages of the mean of the dependent variable. The far right columns show the upper bounds of the 95\% confidence intervals, expressed as a percentage of the mean of the dependent variable. They illustrate the magnitude of the smallest crime effects that can be ruled out with $95 \%$ confidence.

Table 3 shows estimates from the preferred specification, which identifies the effect of army training in Australia by selecting only a sample of birth cohorts from which conscripts were not deployed. For every category of crime, the point estimates are negative. They suggest, for example, that army training reduces overall crime perpetration by $12 \%$ (relative to the mean crime rate), violent crime by $36 \%$, non-violent crime by $6 \%$, property crime by $29 \%$, and drunk driving by $19 \%$. These point estimates also suggest that army training reduces the rate of crimes that result in imprisonment by $68 \%$, with similar results when violent and non-violent crimes are treated separately. However, none of these estimates are statistically different from zero at the $5 \%$ level of significance, so their precision is of primary importance to interpretation. The far right column shows that with $95 \%$ confidence one can rule out any positiveviolent crime effects larger than $3.6 \%$. One also can rule out effects larger than $15 \%$ for drunk driving, $20 \%$ for overall crime, 30\% for property crimes, and 30\% for non-violent crimes. Of course the estimated effects on crimes resulting in imprisonment are less precise. They show that effects larger than $36 \%$ relative to the mean can be ruled out with 95\% confidence.

Table 4 shows the results from models with the same specification, estimated with an expanded sample that is drawn from all 15 birth cohorts subjected to the conscription lotteries. Army training remains the only endogenous variable, despite the fact that some conscripts from the older birth cohorts were deployed to Vietnam. Under the assumption that deployment to Vietnam did not redurecrime, these estimates are treated as conservative upper bounds of the true effects of army training. Because of the expanded sample, this table shows a set of estimates with substantially smaller standard errors. Here the point estimates are quite close to zero for most of the key models. The estimated effect of army service on crime overall is $+0.4 \%$ relative to the mean, $-0.1 \%$ for violent crime, $+0.5 \%$ for non-violent crime, $+0.6 \%$ for property crime, and $+3.5 \%$ for drunk driving. None of these estimates are statistically significant at the $5 \%$ level. 
Again, the far right column is of primary interest. It shows that overall crime effects any larger than $11 \%$ relative to the mean can be ruled out with $95 \%$ confidence. Violent crime effects above $15 \%$ also can be ruled out, as can non-violent crime effects above $12 \%$, property crimes effects above $22 \%$, drunk driving effects above $17 \%$, and effects on crimes resulting in imprisonment above $22 \%$.

Table 5 shows further results generated from the full sample of birth cohorts, this time with the inclusion of deployment to Vienam as a second endogenous regressor. Consistent with the earlier results, the estimated effects of army training are never statistically significant. Further, the point estimates are often negative, again consistent with earlier results, especially for violent crime. Taken in isolation, these estimates rule out violent crimes effects any larger than $21 \%$ relative to the mean rate with $95 \%$ confidence, and they rule out effects larger than $25 \%$ on crime overall. For each outcome, the estimated coefficients of vare not statistically significant, but they are not precise enough to draw any meaningful conclusions about the effects of deployment to Vietnam.

As a further robustness test, we show alternate 2SLS estimates in Tables 6 and 7. These were generated using just-identified models, which are otherwise identical to the models used for Tables 3 and 4, respectively. These estimates are similar to the main results, but slightly less precise. The upper bound of the estimated violent crime effect (6.9\% relative to the mean violent crime rate; see Table 6) is slightly higher than the preferred estimate.

\section{Conclusion}

Recent research suggests that exposure to military combat may lead to violent behavior in later civilian life. However, it has been hypothesized that military service also may lead to civilian violence simply through the training experience, especially the process of 'militarization' and the indoctrination into an intensely masculine culture and belief system, explicitly designed to prepare soldiers for engagement in violent warfare. Because the number of people who receive military training is likely far greater than the number who see combat, the potential importance of this mechanism may be greater than that of combat. Young adults may experience other substantial changes in their cultural environment - including their social, occupational or institutional group affiliation - which can also contribute to their identity. Thus, the extent to which the relatively intense experience of military training induces negative behavior, including 
violence, may be indicative of the vulnerability of young adults to being shaped by culture or environment.

Alternatively, the positive aspects of the military training experience - such as teamwork, respect for authority, and self-discipline - may offset the hypothesized negative effects. Indeed, there is little empirical evidence that military training increases the rate of civilian violence. We contribute to the literature on that question, using the exogenous variation provided by Australia's conscription lotteries, and we also find no evidence for such an effect. Three alternate specifications all yield negative (but statistically insignificant) point estimates. The estimate from our preferred specification allows us to rule out any positive effect larger than $3.6 \%$ (relative to the mean crime rate), with $95 \%$ confidence.

O ur results have caveats and thus may not necessarily apply in other contexts. In particular, the criminal offense data only cover the study population's middle-age years. While young males have higher crime rates, we believe that our estimates are precise enough to be meaningful. Nevertheless, we cannot test for crime effects that occur shortly after army service. However, we can rule out any substantial 'permanent' effects. ${ }^{12}$

Of course these results are also contingent on the specific context of Australian conscript training. It took place for a period of two years at most, and among men who were mainly 20 years of age when they enlisted. Training involved character shaping with positive as well as potentially negative elements. Training skills were wide, varied, and often unrelated to acts of combat. Even among those not deployed to Vietnam, recruits were prepared for a war of covert counter-insurgency rather than for large scale battles. This training may have been less realistic or desensitizing than in the US, because live rounds and 'Quick Kill' training techniques were not used. Australian training also included 'softer' pacification skills, motivated by the need for close cooperation with Vietnamese civilians in Australia's role in the war.

\footnotetext{
${ }^{12}$ While Lindo \& Stoeker's (forthcoming) focus is on all military service (including combat), the violent crime effects that they find are only statistically significant for periods soon after military service. Similar to our analysis, their estimates for later periods are statistically insignificant.
} 
Table 1Descriptive Summary of Criminal Court Data (1994-2010)

\begin{tabular}{|c|c|c|c|c|}
\hline & NSW & VIC & QLD & Total \\
\hline Offenses Heard & 155,506 & 186,278 & 154,323 & 496,107 \\
\hline a Guilty Verdict & 129,705 & 102,540 & 112,232 & 344,477 \\
\hline \multicolumn{5}{|c|}{ Cases with at least 1 Guilty Offense } \\
\hline Violent & 15,399 & 7,883 & 9,628 & 32,91 \\
\hline Non & 53,523 & 36,085 & 41,693 & 131,301 \\
\hline Prop & 8,910 & 7,412 & 5,636 & 21,95 \\
\hline Drun & 22,146 & 9,103 & 10,969 & 42,218 \\
\hline at lest 1 GuiltyOffense & 68,922 & 43,968 & 51,321 & 164,211 \\
\hline \multicolumn{5}{|c|}{ Cases resulting in Imprisonment } \\
\hline Viole & 1,477 & 596 & 771 & 2,84 \\
\hline Non & 2,433 & 1,395 & 1,076 & 4,9 \\
\hline All Cases resultinginimprisonment & 3,910 & 1,991 & 1,847 & 7,7 \\
\hline
\end{tabular}

Notes: The data contain criminal court cases with male defendants born between January 1945 and June 1952, heard during 1994-2010. D efinitions of violent, non-violent, property and drunk driving are in footnote 11. 


\begin{tabular}{|c|c|c|c|c|}
\hline \multirow[b]{3}{*}{ Instrumental variable } & \multicolumn{4}{|c|}{ D ependent Variable } \\
\hline & \multicolumn{2}{|c|}{ Army Service $(r)$} & \multicolumn{2}{|c|}{ D eployment to Vietnam $(v)$} \\
\hline & $\begin{array}{l}\text { estimated } \\
\text { coefficient }\end{array}$ & $\begin{array}{l}\text { (robust } \\
\text { standard } \\
\text { error) }\end{array}$ & $\begin{array}{c}\text { estimated } \\
\text { coefficient }\end{array}$ & $\begin{array}{l}\text { (robust } \\
\text { standard } \\
\text { error) } \\
\end{array}$ \\
\hline \multicolumn{5}{|c|}{ Preferred sample (i.e. restricted to youngest 3 birth cohorts) } \\
\hline ballot outcome (cohort 13) & $.1681^{* * *}$ & $(.0027)$ & & \\
\hline ballot outcome (cohort 14) & $.1529^{* * *}$ & $(.0028)$ & & \\
\hline ballot outcome (cohort 15) & $.1025^{* * *}$ & $(.0024)$ & & \\
\hline F-stat forIV s & 2,844 & & & \\
\hline $\mathrm{N}$ & 210,456 & & & \\
\hline \multicolumn{5}{|c|}{ Full sample (all 15 birth cohorts) } \\
\hline ballot outcome (cohort 1) & $.2471^{* * *}$ & $(.0026)$ & $.0909^{* * *}$ & $(.0019)$ \\
\hline ballot outcome (cohort 2) & $.2377^{* * *}$ & $(.0031)$ & $.0908^{* * *}$ & $(.0022)$ \\
\hline ballot outcome (cohort 3) & $.2132^{* * *}$ & $(.0034)$ & $.0895^{* * *}$ & $(.0025)$ \\
\hline ballot outcome (cohort 4) & $.2197^{* * *}$ & $(.0035)$ & $.1075^{* * *}$ & $(.0027)$ \\
\hline ballot outcome (cohort 5) & $.2030^{* * *}$ & $(.0033)$ & $.0971^{* * *}$ & $(.0025)$ \\
\hline ballot outcome (cohort 6) & $.1968^{* * *}$ & $(.0035)$ & $.1034^{* * *}$ & $(.0027)$ \\
\hline ballot outcome (cohort 7) & $.2015^{* * *}$ & $(.0033)$ & $.0931^{* * *}$ & $(.0024)$ \\
\hline ballot outcome (cohort 8) & $.2154^{* * *}$ & $(.0038)$ & $.0861^{* * *}$ & $(.0027)$ \\
\hline ballot outcome (cohort 9) & $.2011^{* * *}$ & $(.0031)$ & $.0683^{* * *}$ & $(.0021)$ \\
\hline ballot outcome (cohort 10) & $.2036^{* * *}$ & $(.0040)$ & $.0468^{* * *}$ & (.0023) \\
\hline ballot outcome (cohort 11) & $.1935^{* * *}$ & $(.0039)$ & $.0246^{* * *}$ & $(.0018)$ \\
\hline ballot outcome (cohort 12) & $.1870^{* * *}$ & $(.0033)$ & $.0049^{* * *}$ & $(.0010)$ \\
\hline ballot outcome (cohort 13) & $.1681^{* * *}$ & $(.0027)$ & .0004 & $(.0007)$ \\
\hline ballot outcome (cohort 14) & $.1529^{* * *}$ & $(.0028)$ & .0006 & $(.0006)$ \\
\hline ballot outcome (cohort 15) & $.1025^{* * *}$ & $(.0024)$ & $-.0010^{* *}$ & $(.0004)$ \\
\hline F-stat for IV s & \multicolumn{2}{|c|}{3,833} & \multicolumn{2}{|c|}{947} \\
\hline $\begin{array}{l}\text { Angist-Pische Multivaniate } \\
\text { F-stat }\end{array}$ & \multicolumn{2}{|c|}{1,860} & \multicolumn{2}{|c|}{919} \\
\hline $\mathrm{N}$ & \multicolumn{2}{|c|}{$1,030,740$} & \multicolumn{2}{|c|}{$1,030,740$} \\
\hline
\end{tabular}

Notes: The upper panel reports key estimates from a first-stage regression of army service (r) on 3 instruments (a binary conscription ballot outcome indicator for each birth cohort). The lower panel reports corresponding first-stage regression results for army service and for deployment to 
Vietnam (v), using the full sample, drawn from all 15 birth cohorts. Each regression includes birth cohort fixed-effects. ${ }^{*} \mathrm{p}<0.05,{ }^{* *} \mathrm{p}<0.01,{ }^{* * *} \mathrm{p}<0.001$ 
Table 3 2SLS Results - Preferred Specification (Non-Deployed Cohorts Only)

\begin{tabular}{|c|c|c|c|c|}
\hline \multirow[b]{2}{*}{ Endogenous variable } & \multirow{2}{*}{$\begin{array}{c}\text { mean of } \\
\text { dependen } \\
\text { variable }\end{array}$} & \multicolumn{3}{|c|}{ Estimated 2SLS effects } \\
\hline & & $\begin{array}{l}\text { Point estimates } \\
\text { (robust S.E.s) }\end{array}$ & $\begin{array}{l}\text { Point estimate } \\
\text { as } \% \text { of mean }\end{array}$ & $\begin{array}{c}95 \% \text { CI } \\
\text { Upper bound } \\
\text { as \% of mean }\end{array}$ \\
\hline & & A. Dependent & ariable: All crim & \\
\hline \multirow[t]{2}{*}{ Army service $(r)$} & .326 & $(.0526)$ & $-12 \%$ & $20 \%$ \\
\hline & \multicolumn{4}{|c|}{ B. D ependent Variable: Violent crimes } \\
\hline \multirow[t]{2}{*}{ Army service $(r)$} & .064 & $(.0129)$ & $-36 \%$ & $3.6 \%$ \\
\hline & \multicolumn{4}{|c|}{ C. Dependent Variable: Non-violent crimes } \\
\hline \multirow[t]{2}{*}{ Army service $(r)$} & .262 & $(.0477)$ & $-6 \%$ & $30 \%$ \\
\hline & \multicolumn{4}{|c|}{ D. D ependent Variable: Property crimes } \\
\hline \multirow[t]{2}{*}{ Army service $(r)$} & .045 & $(.0133)$ & $-29 \%$ & $30 \%$ \\
\hline & \multicolumn{4}{|c|}{ E. D runk driving Crimes } \\
\hline \multirow[t]{2}{*}{ Army service $(r)$} & .081 & $(.0141)$ & $-19 \%$ & $15 \%$ \\
\hline & \multicolumn{4}{|c|}{ F. Crimes resulting in Imprisonment } \\
\hline \multirow[t]{2}{*}{ Army service $(r)$} & .016 & $(.0083)$ & $-68 \%$ & $36 \%$ \\
\hline & \multicolumn{4}{|c|}{ G. Violent crimes resulting in Imprisonment } \\
\hline \multirow[t]{2}{*}{ Army service $(r)$} & .005 & $(.0037)$ & $-58 \%$ & $81 \%$ \\
\hline & \multicolumn{4}{|c|}{$\underline{\text { H. Non-violent crimes resulting in Imprisonment }}$} \\
\hline \multirow[t]{2}{*}{ Army service $(r)$} & .010 & $(.0066)$ & $-72 \%$ & $51 \%$ \\
\hline & \multicolumn{4}{|c|}{ I. Property crimes resulting in Imprisonment } \\
\hline Army service $(r)$ & .006 & $(.0051)$ & $-15 \%$ & $143 \%$ \\
\hline
\end{tabular}

Notes: This table shows 2SLS estimates of the effect of army training on subsequent crime perpetration. Each of the nine panels contains results for a particular category of criminal offenses. Cases with one or more guilty verdict are included. The sample is restricted to men in the youngest three conscription-eligible birth cohorts (those born between January 1951 and June 1952). Conscripts from these cohorts served only in Australia. A GLS group-means approach is utilized, where the groups are exact dates of birth (DOBs) and the weights are the number of men with each DOB living in NSW, VIC or QLD. In each model, N = 547 DOBs, representing 127,478 men. Each model includes birth cohort fixed effects. Robust standard errors are in parentheses. $* \mathrm{p}<0.05,{ }^{* *} \mathrm{p}<0.01,{ }^{* * *} \mathrm{p}<0.001$ 


\begin{tabular}{|c|c|c|c|c|}
\hline \multirow[b]{2}{*}{ Endogenous variable } & \multirow[b]{2}{*}{$\begin{array}{c}\text { mean of } \\
\text { dependent } \\
\text { variable }\end{array}$} & \multicolumn{3}{|c|}{ Estimated 2SLS effects } \\
\hline & & $\begin{array}{l}\text { Point estimates } \\
\text { (robust S.E.S) }\end{array}$ & $\begin{array}{l}\text { Point estimate } \\
\text { as } \% \text { of mean }\end{array}$ & $\begin{array}{c}95 \% \text { CI } \\
\text { Upper bound } \\
\text { as \% of mean }\end{array}$ \\
\hline & \multicolumn{4}{|c|}{ A. Dependent Variable: All crimes } \\
\hline \multirow[t]{2}{*}{ Army service $(r)$} & .264 & $(.0144)$ & $0.4 \%$ & $11 \%$ \\
\hline & \multicolumn{4}{|c|}{ B. D ependent Variable: Violent crimes } \\
\hline \multirow[t]{2}{*}{ Army service $(r)$} & .053 & $(.0041)$ & $-0.1 \%$ & $15 \%$ \\
\hline & \multicolumn{4}{|c|}{ C. D ependent Variable: Non-violent crimes } \\
\hline \multirow[t]{2}{*}{ Army service $(r)$} & .211 & $(.0128)$ & $0.5 \%$ & $12 \%$ \\
\hline & \multicolumn{4}{|c|}{ D. D ependent Variable: Property crimes } \\
\hline \multirow[t]{2}{*}{ Army service $(r)$} & .035 & $(.0039)$ & $0.6 \%$ & $22 \%$ \\
\hline & \multicolumn{4}{|c|}{ E. D runk driving Crimes } \\
\hline \multirow[t]{2}{*}{ Army service $(r)$} & .068 & $(.0046)$ & $3.5 \%$ & $17 \%$ \\
\hline & \multicolumn{4}{|c|}{ F. Crimes resulting in Imprisonment } \\
\hline \multirow[t]{2}{*}{ Army service $(r)$} & .012 & $(.0024)$ & $-16.1 \%$ & $22 \%$ \\
\hline & \multicolumn{4}{|c|}{ G. Violent crimes resulting in Imprisonment } \\
\hline \multirow[t]{2}{*}{ Army service $(r)$} & .005 & $(.0013)$ & $30.3 \%$ & $84 \%$ \\
\hline & \multicolumn{4}{|c|}{ H. Non-violent crimes resulting in Imprisonment } \\
\hline \multirow[t]{2}{*}{ Army service $(r)$} & .008 & $(.0018)$ & $-43.0 \%$ & $3 \%$ \\
\hline & \multicolumn{4}{|c|}{ I. Property crimes resulting in Imprisonment } \\
\hline Army service $(r)$ & .005 & $(.0014)$ & $-43.1 \%$ & $17 \%$ \\
\hline
\end{tabular}

Notes: This table shows 2SLS estimates of the effect of army training on subsequent crime perpetration. Each of the nine panels contains results for a particular category of criminal offenses. Cases with one or more guilty verdict are included. The sample includes men from all 15 conscription-eligible birth cohorts (those born between January 1945 and June 1952). A GLS group-means approach is utilised, where the groups are exact dates of birth (DOBs) and the weights are the number of men with each D O B living in NSW, VIC or QLD. In each model, N = 2,738 D OBs, representing 621,283 men. Each model includes birth cohort fixed effects. Robust standard errors are in parentheses. $* \mathrm{p}<0.05, * * \mathrm{p}<0.01, * * * \mathrm{p}<0.001$ 


\begin{tabular}{|c|c|c|c|c|}
\hline \multirow[b]{2}{*}{ Endogenous variables } & \multirow[b]{2}{*}{$\begin{array}{l}\text { mean of } \\
\text { dependent } \\
\text { variable }\end{array}$} & \multicolumn{3}{|c|}{ Estimated 2SLS effects } \\
\hline & & $\begin{array}{c}\text { point estimates } \\
\text { (robust S.E.s) }\end{array}$ & $\begin{array}{l}\text { point estimate } \\
\text { as } \% \text { of mean }\end{array}$ & $\begin{array}{c}95 \% \text { CI } \\
\text { Upper bound } \\
\text { as \% of mean } \\
\end{array}$ \\
\hline & \multicolumn{4}{|c|}{ A. Dependent Variable: All crimes } \\
\hline Army service $(r)$ & \multirow{2}{*}{.264} & $(.0364)$ & $-2 \%$ & $25 \%$ \\
\hline D eployment to Vietnam $(v)$ & & $(.0946)$ & $8 \%$ & $78 \%$ \\
\hline & \multicolumn{4}{|c|}{ B. D ependent Variable: Violent crimes } \\
\hline Army service $(r)$ & \multirow{2}{*}{.053} & $(.0096)$ & $-15 \%$ & $21 \%$ \\
\hline D eployment to Vietnam $(v)$ & & $(.0253)$ & $46 \%$ & $139 \%$ \\
\hline & \multicolumn{4}{|c|}{ C. Dependent Variable: Non-violent crimes } \\
\hline Army service $(r)$ & \multirow{2}{*}{.211} & $(.0326)$ & $1 \%$ & $31 \%$ \\
\hline D eployment to Vietnam $(v)$ & & $(.0843)$ & $-2 \%$ & $76 \%$ \\
\hline \multirow{3}{*}{$\begin{array}{l}\text { Army service }(r) \\
\text { D eployment to Vietnam }(v)\end{array}$} & \multicolumn{4}{|c|}{ D. D ependent Variable: Property crimes } \\
\hline & \multirow{2}{*}{.035} & $(.0100)$ & $-19 \%$ & $37 \%$ \\
\hline & & $(.0253)$ & $60 \%$ & $201 \%$ \\
\hline \multirow{3}{*}{$\begin{array}{l}\text { Army service }(r) \\
\text { D eployment to Vietnam }(v)\end{array}$} & \multicolumn{4}{|c|}{ E. D runk driving Crimes } \\
\hline & \multirow{2}{*}{.068} & $(.0104)$ & $2 \%$ & $32 \%$ \\
\hline & & $(.0279)$ & $5 \%$ & $85 \%$ \\
\hline \multirow{3}{*}{$\begin{array}{l}\text { Army service }(r) \\
\text { D eployment to Vietnam }(v)\end{array}$} & \multicolumn{4}{|c|}{ F. Crimes resulting in Imprisonment } \\
\hline & \multirow{2}{*}{.012} & $(.0062)$ & $-31 \%$ & $32 \%$ \\
\hline & & $(.0162)$ & $46 \%$ & $301 \%$ \\
\hline \multirow{3}{*}{$\begin{array}{l}\text { Army service }(r) \\
\text { D eployment to }(v)\end{array}$} & \multicolumn{4}{|c|}{ G. Violent crimes resulting in Imprisonment } \\
\hline & \multirow{2}{*}{.005} & $(.0030)$ & $-2 \%$ & $126 \%$ \\
\hline & & $(.0079)$ & $100 \%$ & $439 \%$ \\
\hline \multirow{4}{*}{$\begin{array}{l}\text { Army service }(r) \\
\text { D eployment to Vietnam }(v)\end{array}$} & \multicolumn{4}{|c|}{$\underline{\text { H. Non-violent crimes resulting in Imprisonment }}$} \\
\hline & \multirow{2}{*}{.008} & $(.0049)$ & $-48 \%$ & $74 \%$ \\
\hline & & $(.0125)$ & $14 \%$ & $325 \%$ \\
\hline & \multicolumn{4}{|c|}{ I. Property crimes resulting in Imprisonment } \\
\hline \multirow{2}{*}{$\begin{array}{l}\text { Army service }(r) \\
\text { D eployment to Vietnam }(v)\end{array}$} & \multirow{2}{*}{.005} & $(.0039)$ & $-45 \%$ & $118 \%$ \\
\hline & & $(.0098)$ & $7 \%$ & $419 \%$ \\
\hline
\end{tabular}

Notes: This table shows 2SLS estimates of the independent effects of army service and the additional effects of deployment to Vietnam (as per equation (3)) on subsequent crime perpetration. Each of the nine panels contains results for a particular category of criminal 
offenses. Cases with one or more guilty verdict are included. The sample includes men from all 15 conscription-eligible birth cohorts (those born between January 1945 and June 1952). A G LS group-means approach is utilised, where the groups are exact dates of birth (DOBs) and the weights are the number of men with each D O B living in NSW, VIC or QLD. In each model, N = 2,738 D OBs, representing 621,283 men. Each model includes birth cohort fixed effects. Robust standard errors are in parentheses. ${ }^{*} \mathrm{p}<0.05, * * \mathrm{p}<0.01,{ }^{* * *} \mathrm{p}<0.001$ 
Table 6 Robustness Test - 2SLS Results - Just-Identified Specification (Non-Deployed Cohorts Only)

\begin{tabular}{|c|c|c|c|c|}
\hline \multirow[b]{2}{*}{ Endogenous variable } & \multirow{2}{*}{$\begin{array}{c}\text { mean of } \\
\text { dependent } \\
\text { variable }\end{array}$} & \multicolumn{3}{|c|}{ Estimated 2SLS effects } \\
\hline & & $\begin{array}{l}\text { Point estimates } \\
\text { (robust S.E.s) }\end{array}$ & $\begin{array}{l}\text { Point estimate } \\
\text { as \% of mean }\end{array}$ & $\begin{array}{l}\text { Upper bound } \\
\text { as \% of mean }\end{array}$ \\
\hline \multirow[b]{2}{*}{ Army service $(r)$} & \multicolumn{4}{|c|}{ A. D ependent Variable: All crimes } \\
\hline & .326 & $(.0527)$ & $-15 \%$ & $17 \%$ \\
\hline \multirow{3}{*}{ Army service $(r)$} & \multicolumn{4}{|c|}{ B. Dependent Variable: Violent crimes } \\
\hline & .064 & $(.0132)$ & $-33 \%$ & $6.9 \%$ \\
\hline & \multicolumn{4}{|c|}{ C. D ependent Variable: Non-violent crimes } \\
\hline \multirow[t]{2}{*}{ Army service $(r)$} & .262 & $(.0473)$ & $-11 \%$ & $25 \%$ \\
\hline & \multicolumn{4}{|c|}{ D. D ependent Variable: Property crimes } \\
\hline \multirow[t]{2}{*}{ Army service $(r)$} & .045 & $(.0134)$ & $-28 \%$ & $31 \%$ \\
\hline & \multicolumn{4}{|c|}{ E. Drunk driving Crimes } \\
\hline \multirow[t]{2}{*}{ Army service $(r)$} & .081 & $(.0150)$ & $-18 \%$ & $18 \%$ \\
\hline & & F. Crimes resulti & gin Imprisonme & \\
\hline \multirow[t]{2}{*}{ Army service $(r)$} & .016 & $(.0083)$ & $-76 \%$ & $29 \%$ \\
\hline & \multicolumn{4}{|c|}{ G. Violent crimes resulting in Imprisonment } \\
\hline \multirow[t]{2}{*}{ Army service $(r)$} & .005 & $(.0037)$ & $-62 \%$ & $79 \%$ \\
\hline & \multicolumn{4}{|c|}{ H. Non-violent crimes resulting in Imprisonment } \\
\hline \multirow[t]{2}{*}{ Army service $(r)$} & .010 & $(.0066)$ & $-84 \%$ & $42 \%$ \\
\hline & \multicolumn{4}{|c|}{ I. Property crimes resulting in Imprisonment } \\
\hline Army service $(r)$ & .006 & $(.0052)$ & $-14 \%$ & $145 \%$ \\
\hline
\end{tabular}

Notes: This table shows an alternate set of 2SLS results as a robustness test. These results were generated using a set of just-identified models, which are otherwise identical to the models used for the Table 3 results. See also Table 3 notes. 
Table 7 Robustness Test - 2SLS Results - Just-Identified Specification (All 15 Cohorts)

\begin{tabular}{|c|c|c|c|c|}
\hline \multirow[b]{2}{*}{ Endogenous variable } & \multirow{2}{*}{$\begin{array}{c}\text { mean of } \\
\text { dependent } \\
\text { variable }\end{array}$} & \multicolumn{3}{|c|}{ Estimated 2SLS effects } \\
\hline & & $\begin{array}{l}\text { Point estimates } \\
\text { (robust S.E.s) }\end{array}$ & $\begin{array}{l}\text { Point estimate } \\
\text { as } \% \text { of mean }\end{array}$ & $\begin{array}{l}\text { Upper bound } \\
\text { as \% of mean }\end{array}$ \\
\hline & & $\underline{\text { A. D ependent }}$ & ariable: All crim & \\
\hline \multirow[t]{2}{*}{ Army service $(r)$} & .264 & $(.0152)$ & $-0.9 \%$ & $10 \%$ \\
\hline & \multicolumn{4}{|c|}{ B. Dependent Variable: Violent crimes } \\
\hline \multirow[t]{2}{*}{ Army service $(r)$} & .053 & $(.0042)$ & $-1.2 \%$ & $14 \%$ \\
\hline & \multicolumn{4}{|c|}{ C. D ependent Variable: Non-violent crimes } \\
\hline \multirow[t]{2}{*}{ Army service $(r)$} & .211 & $(.0135)$ & $-0.8 \%$ & $12 \%$ \\
\hline & \multicolumn{4}{|c|}{ D. D ependent Variable: Property crimes } \\
\hline \multirow[t]{2}{*}{ Army service $(r)$} & .035 & $(.0041)$ & $-0.8 \%$ & $22 \%$ \\
\hline & \multicolumn{4}{|c|}{ E. D runk driving Crimes } \\
\hline \multirow[t]{2}{*}{ Army service $(r)$} & .068 & $(.0048)$ & $2.5 \%$ & $16 \%$ \\
\hline & \multicolumn{4}{|c|}{ F. Crimes resulting in Imprisonment } \\
\hline \multirow[t]{2}{*}{ Army service $(r)$} & .012 & $(.0026)$ & $-21.0 \%$ & $19 \%$ \\
\hline & \multicolumn{4}{|c|}{ G. Violent crimes resulting in Imprisonment } \\
\hline \multirow[t]{2}{*}{ Army service $(r)$} & .005 & $(.0013)$ & $25.9 \%$ & $82 \%$ \\
\hline & \multicolumn{4}{|c|}{ H. Non-violent crimes resulting in Imprisonment } \\
\hline \multirow[t]{2}{*}{ Army service $(r)$} & .008 & $(.0019)$ & $-48.3 \%$ & $0 \%$ \\
\hline & \multicolumn{4}{|c|}{ I. Property crimes resulting in Imprisonment } \\
\hline Army service $(r)$ & .005 & $(.0015)$ & $-39.9 \%$ & $24 \%$ \\
\hline
\end{tabular}

Notes: This table shows an alternate set of 2SLS results as a robustness test. These results were generated using a set of just-identified models, which are otherwise identical to the models used for the Table 4 results. See also Table 4 notes. 
Figure 1 Frequency Counts of Criminal Court Cases with a Guilty Verdict by State and Year

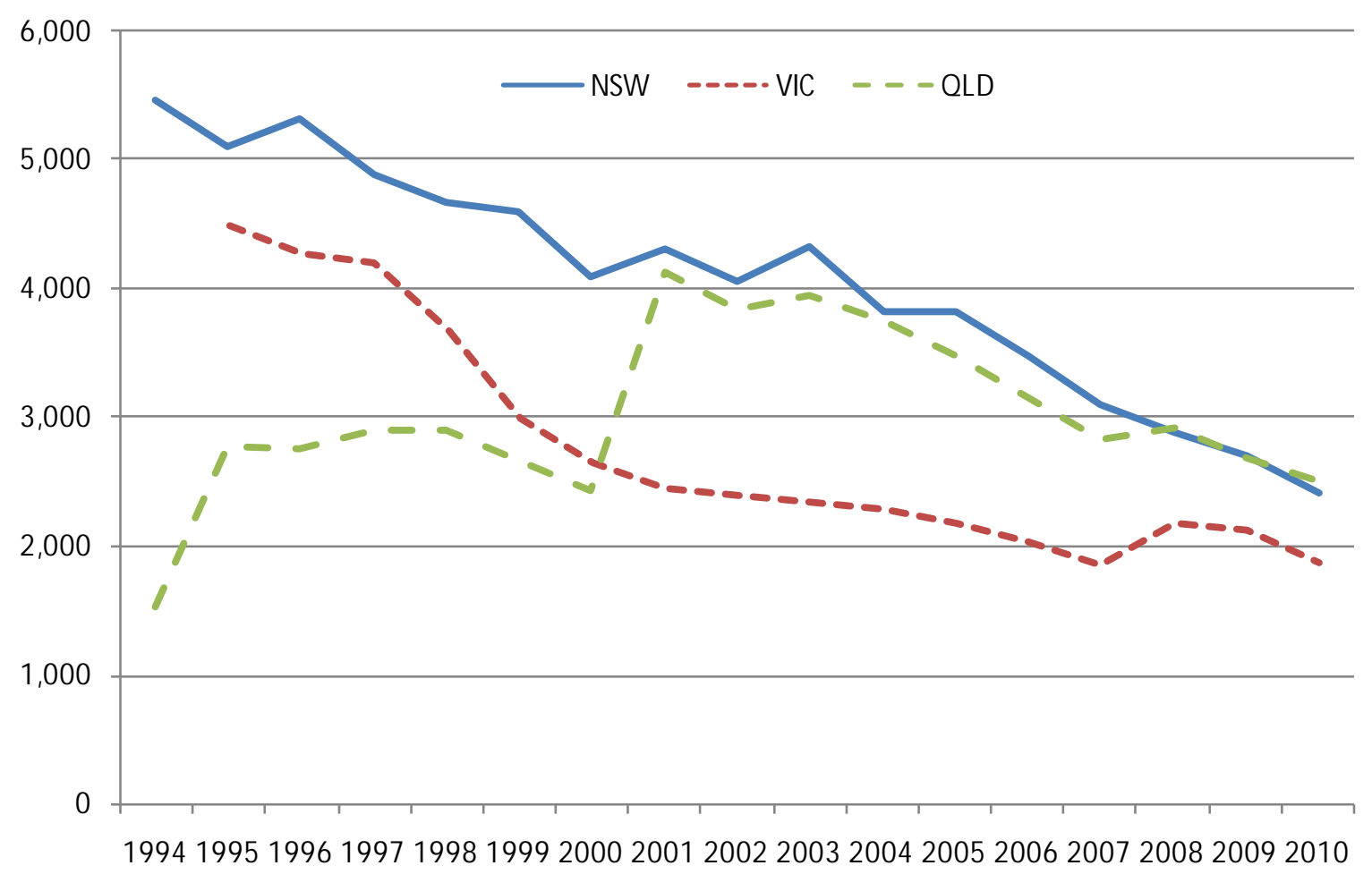

Note: This figure shows annual counts of criminal court cases with at least one guilty verdict, for male defendants born between January 1945 and June 1952, heard during 1994-2010, for each of Australia's three largest states. Data for cases heard prior to 2001 in QLD provincial courts are unavailable. 
Figure 2 Ratio of Crimes Committed to Population by 6-month Birth Cohort and Conscription Ballot Outcome

A. All crimes

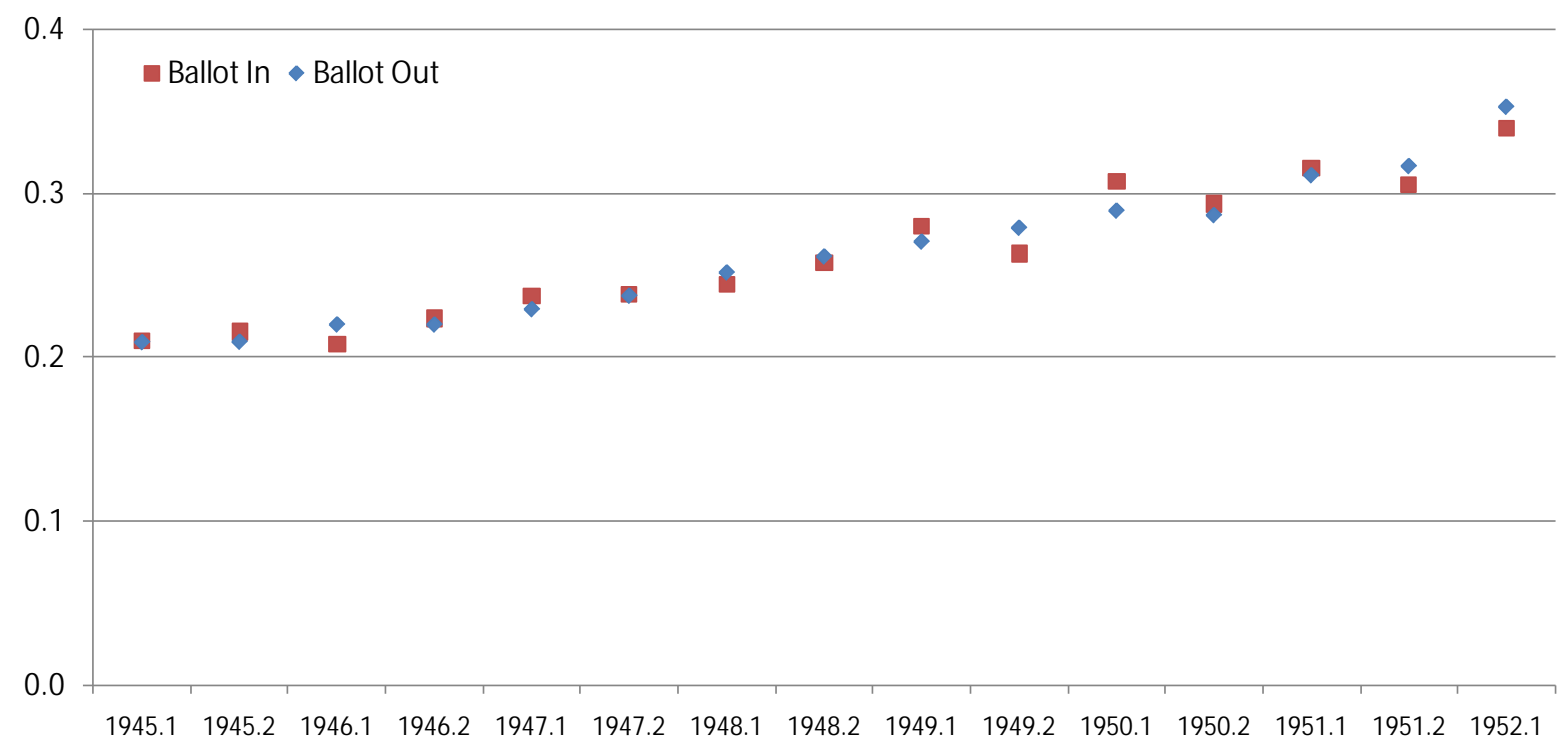

B. Violent crimes
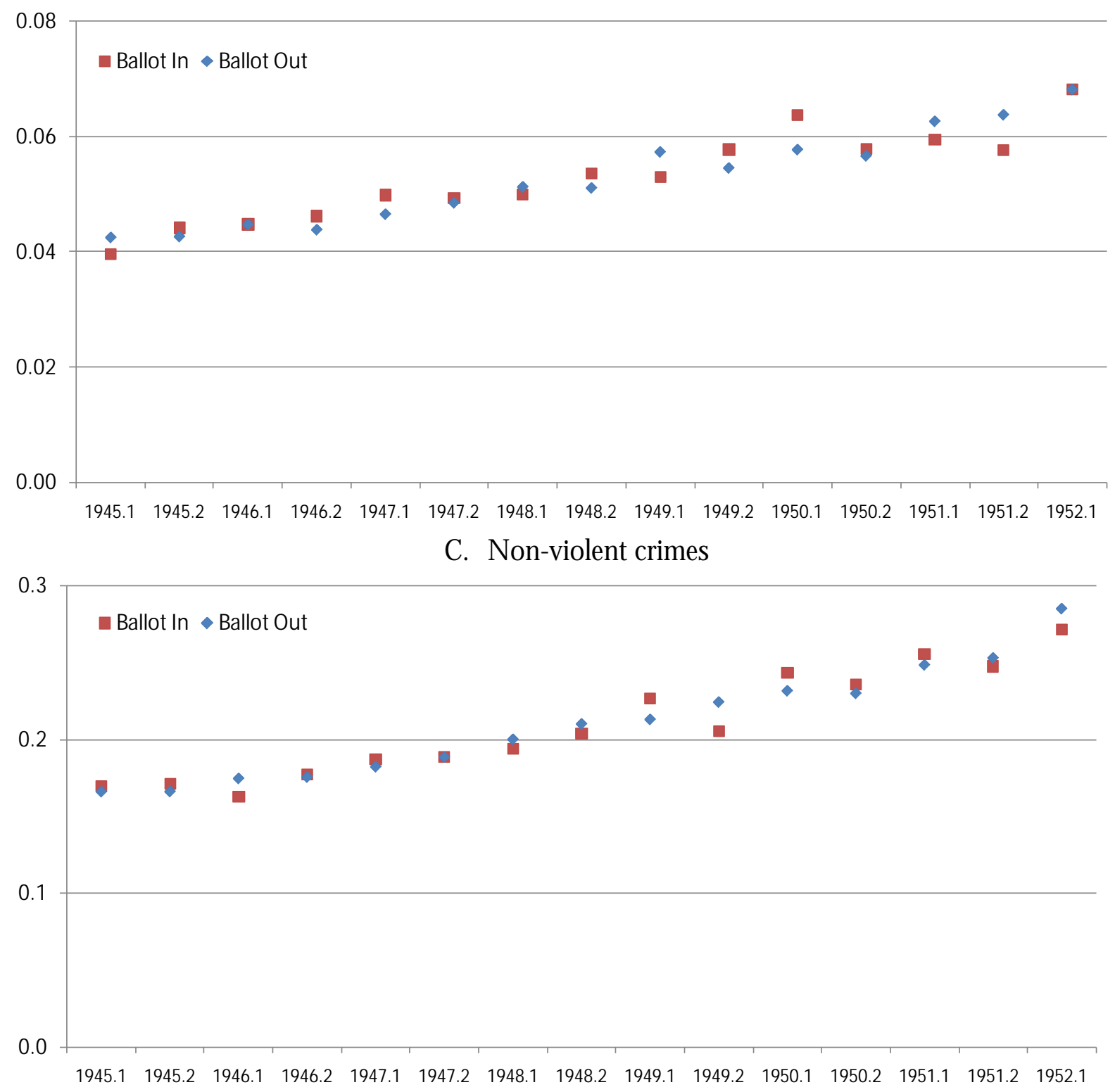
D. Property crimes

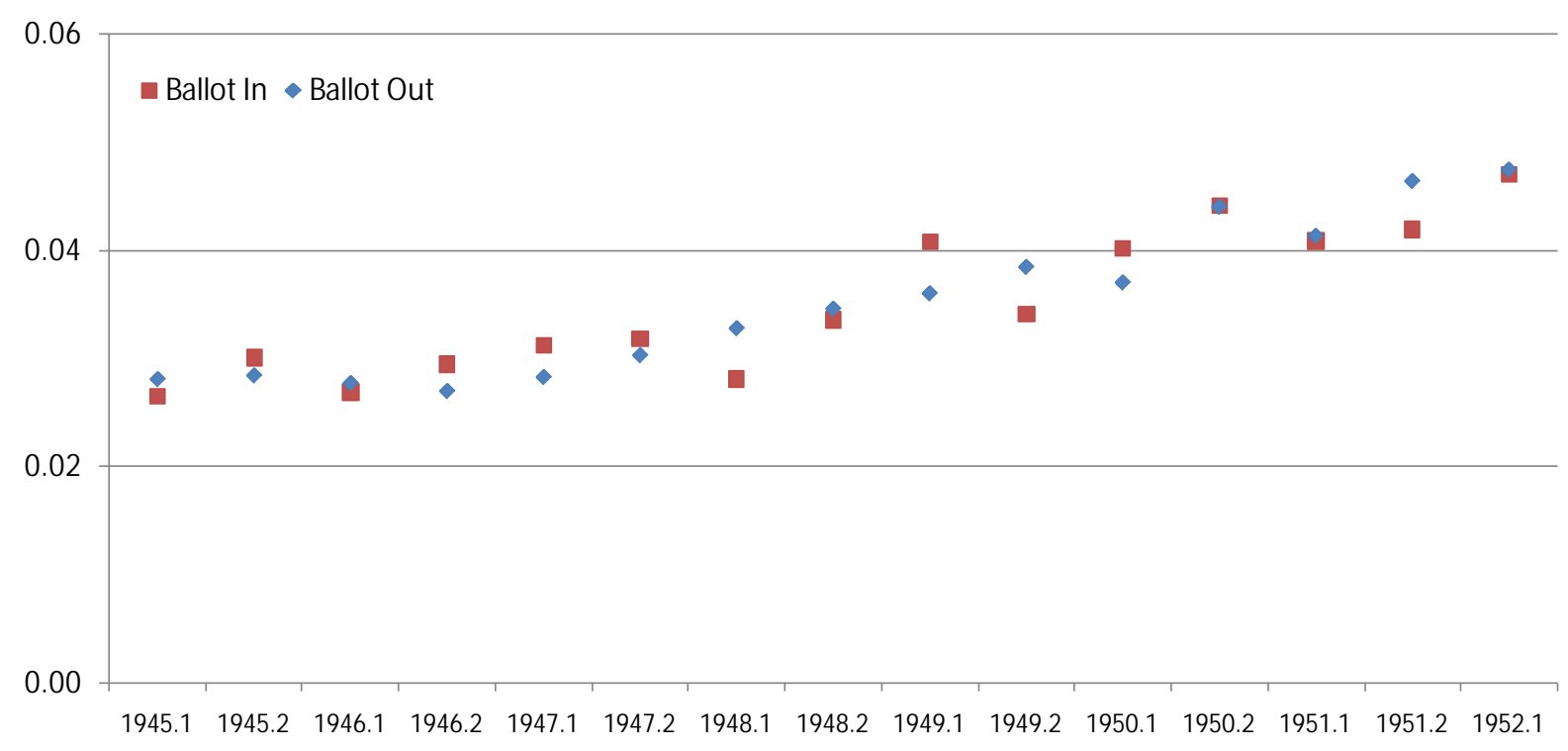

E. D runk driving crimes

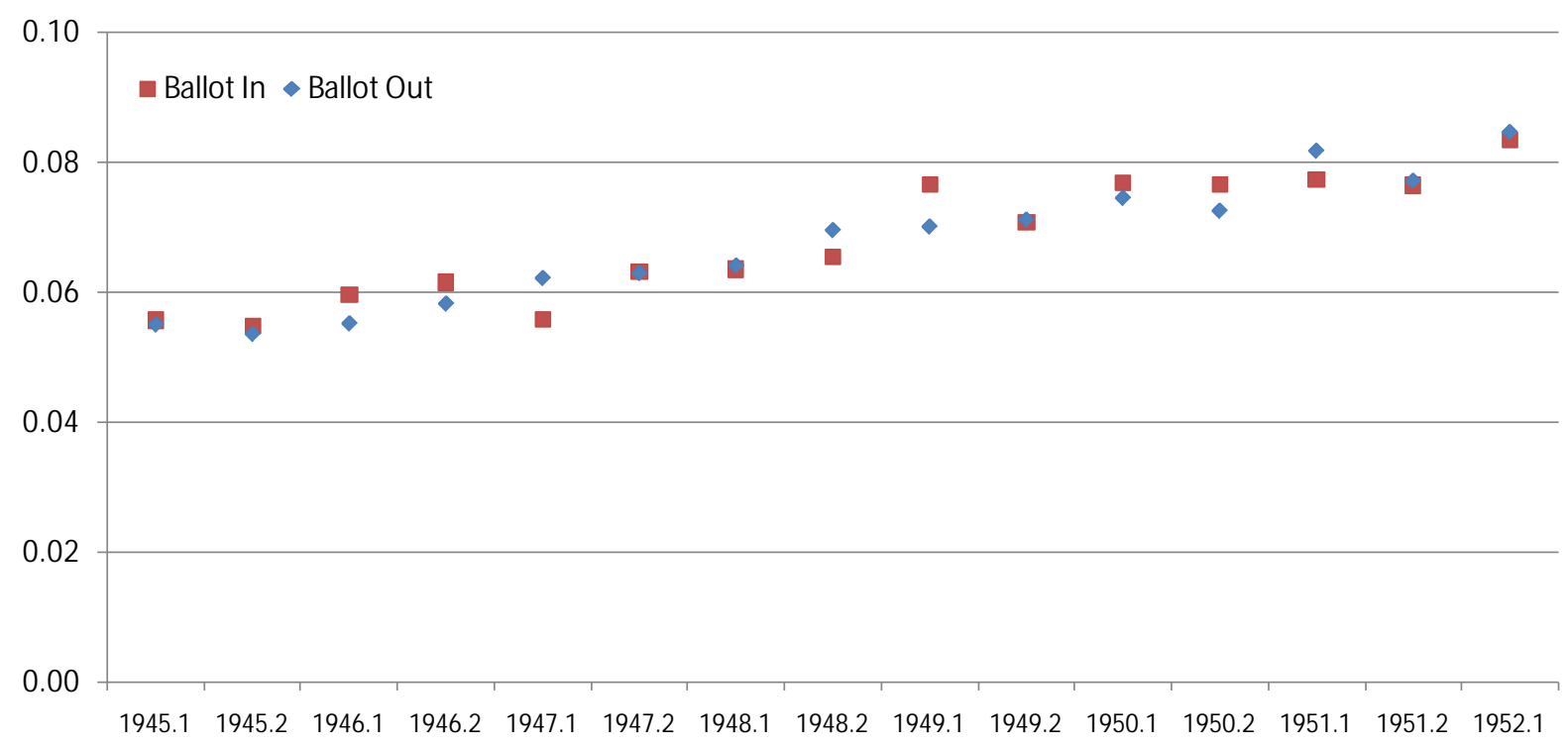

F. Crimes resulting in imprisonment

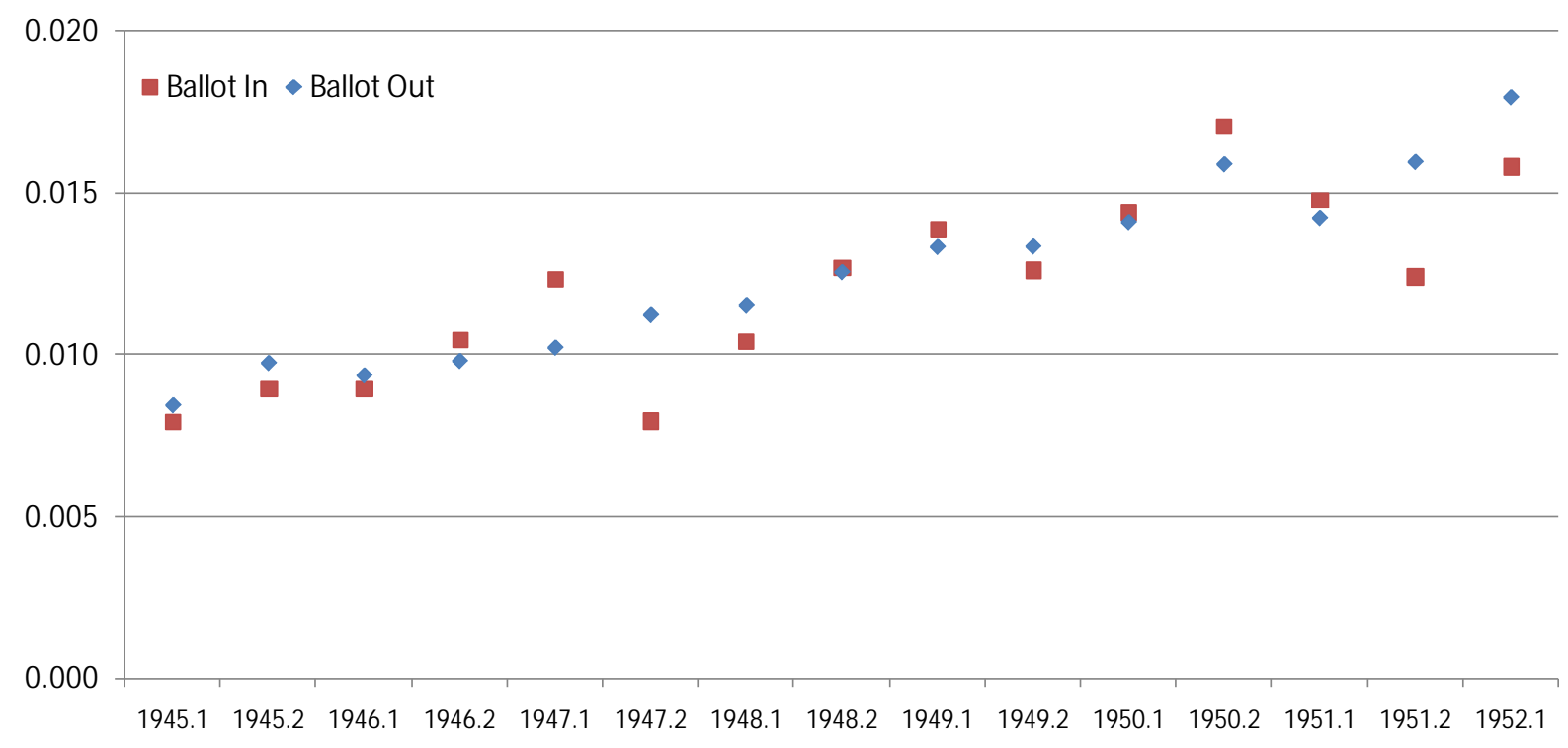


G. Violent crimes resulting in imprisonment

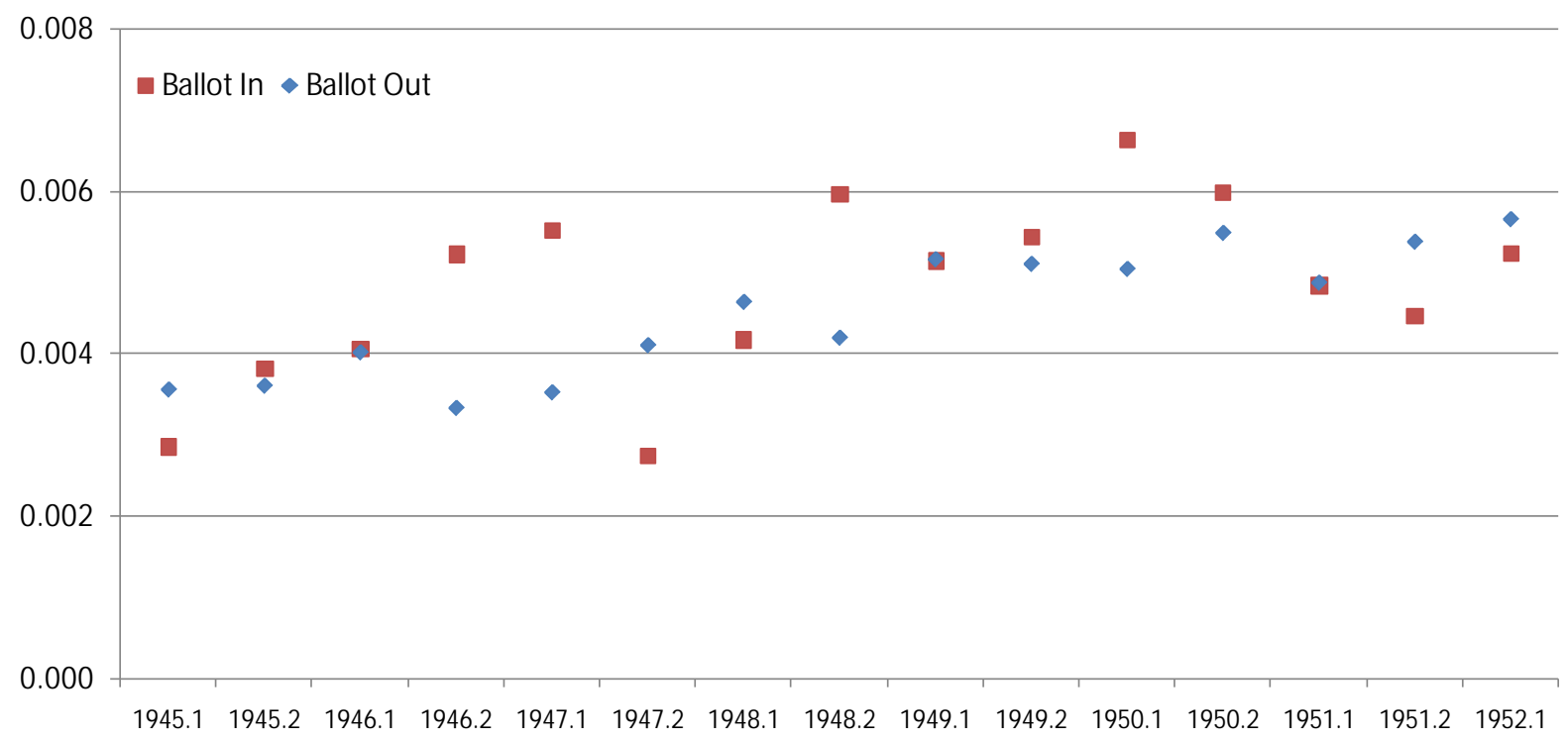

$\mathrm{H}$. Non-violent crimes resulting in imprisonment

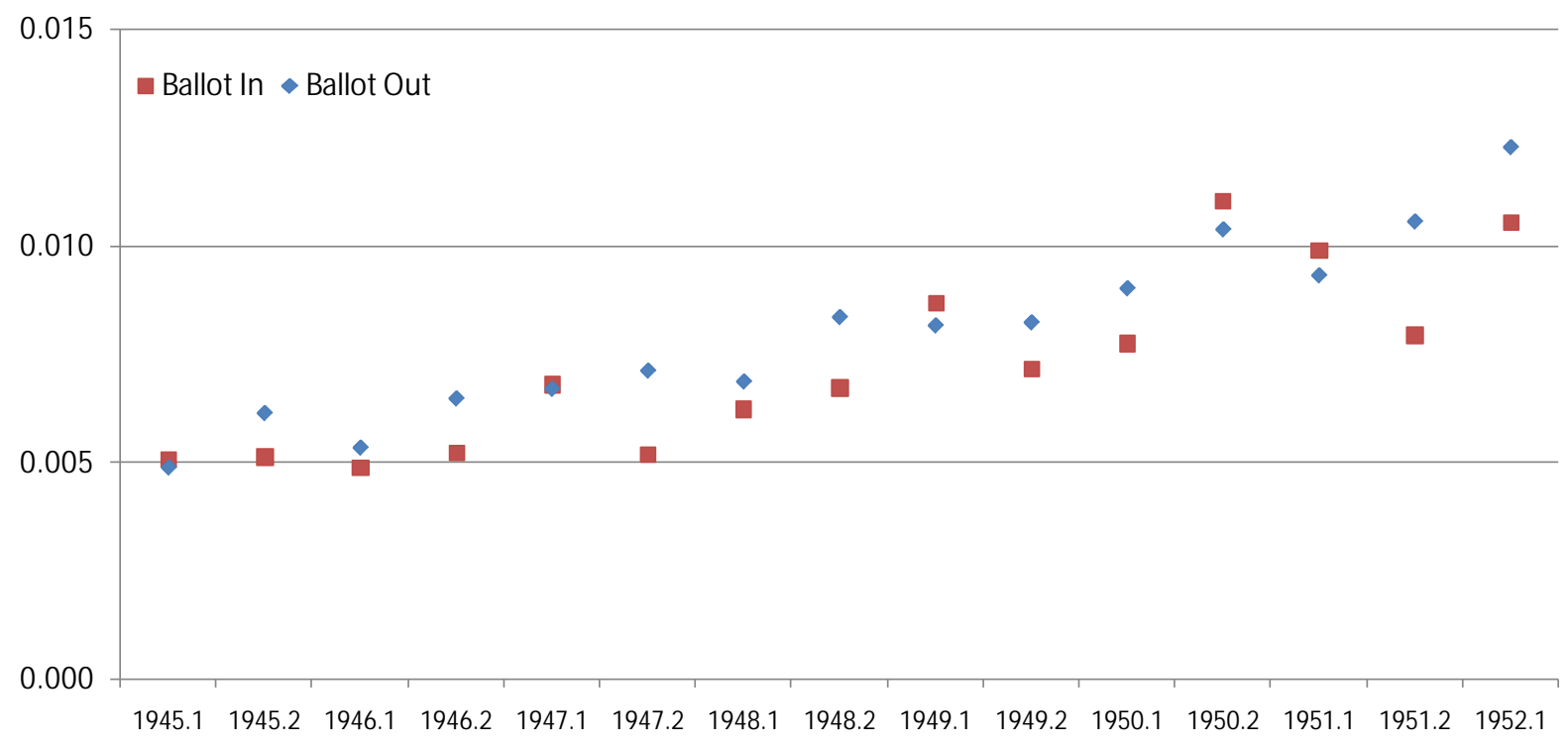

I. Property crimes resulting in imprisonment

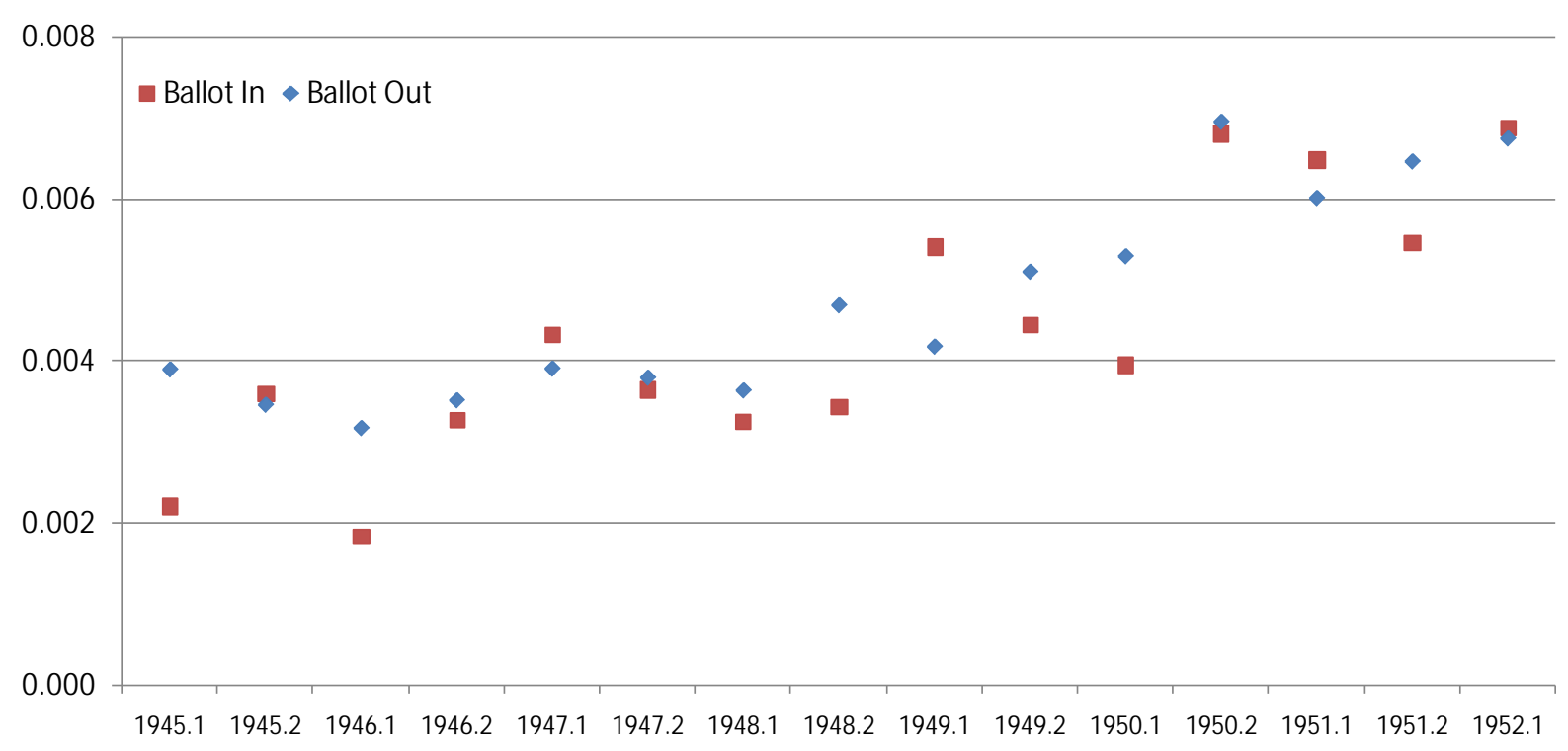




\section{References}

ABS (2008), A ustralian Standard OffenceClassification (ASOC), 2008 (2nd Edition) ABS CatalogreNa 1234.0 (Canberra: Australian Bureau of Statistics).

Agnew, Robert (1992), 'Foundation for a general strain theory of crime and delinquency', Crimindogy, 30 (1), 47-86.

Almond, Douglas and Currie, Janet (2011a), 'Killing Me Softly: The Fetal Origins Hypothesis', Jarmal of EconamicPespetives 25 (3), 153-72.

--- (2011b), 'Human Capital Development before Age Five', in Orley Ashenfelter and David E. Card (eds.), Handbook of Labor Economics, (4b), 1315-486.

Anderson, C and Bushman, B (2002), 'Human Aggression', Amual Reiewof Psydhdog, 53, 27-51.

Angrist, Joshua D . (1990), 'Lifetime Earnings and the Vietnam Era D raft Lottery: Evidence from

Social Security Administrative Records', Ameican EconomicReiew 80 (3), 313-36.

--- (1991), 'Grouped-data estimation and testing in simple labor-supply models', Jaumal of Econominics, 47, 243-66.

--- (1993), 'The Effect Of Veterans Benefits On Education And Earnings', Industrial and Labor Reations Review 46 (4), 637-52.

--- (1998), 'Estimating the Labor Market Impact of Voluntary Military Service Using Social Security Data on Military Applicants', Economerica, 66 (2), 249-88.

Angrist, Joshua D. and Krueger, Alan B (1994), 'Why Do World War II Veterans Earn More than Nonveterans?', Jamal of Labor Economics, 12 (1), 74-97.

Angrist, Joshua D. and Pischke, Jorn-Steffen (2009), Mostly Hammess Economerics (Princeton: Princeton University Press).

Angrist, Joshua D. and Chen, Stacey H (2011), 'Schooling and the Vietnam-Era GI Bill: Evidence from the D raft Lottery', Amerian EconomicJaumal: AppliedEconomics 3, 96-118.

Angrist, Joshua D., Imbens, Guido W, and Rubin, Donald (1996), 'Identification of Causal Effects Using Instrumental Variables', Jaumal atheAmeican Statistical Assoiation, 91 (434 (Jun., 1996)), 444-55.

Angrist, Joshua D., Chen, Stacey H., and Song, Jae (2011), 'Long-term Consequences of Vietnam-Era Conscription: New Estimates Using Social Security D ata', AmmicanEconomic Reien Papers \& Proweding, 101 (3), 334-38.

Arkin, W and D obrofsky, L (1978), 'Military socialization and masculinity', Jaumal of Social Issues, 34, 151-68.

Autor, David H, Duggan, Mark G, and Lyle, David S (2011), 'Battle Scars? The Puzzling Decline in Employment and Rise in Disability Receipt among Vietnam Era Veterans', Ameican EconomicReviev Papess \& Procedings, 101 (3), 339-44. 
Bauer, Thomas K., et al. (2012), 'Evaluating the Labor Market Effects of Compulsory Military Service', EuropeanEconomicReview 56 (40), 814-29.

Bound, John and Turner, Sarah (2002), 'Going to War and Going to College: Did World War II and the G.I. Bill Increase Educational Attainment for Returning Veterans?', Jaumal of LabarEconamics, 20 (4), 784-815.

Card, David and Cardoso, Ana Rute (2012), 'Can Compulsory Military Service Raise Civilian Wages? Evidence from the Peacetime Draft in Portugal', Ameican Econamic Jaumal: Appliel Econamics 4 (4), 57-93.

Conley, Dalton and Heerwig, Jennifer A (2012), 'The Long-Term Effects of Military Conscription on Mortality: Estimates from the Vietnam-era D raft Lottery', Demogaphy, 49 (3), 841-55.

Currie, Janet and Tekin, Erdal (2012), 'Understanding the Cycle: Childhood Maltreatment and Future Crime', Jaumal of HumanResarces, 45 (2), 509-49.

Dobkin, Carlos and Shabani, Reza (2009), 'The Health Effects of Military Service: Evidence from the Vietnam D raft', EconomicInquiry, 47 (1), 69-80.

D onnelly, R (2001), TheSchegrilleExpeience The Officer Training Unit, Scherille 1965-73 (St Lucia: University of Queensland Press).

Ebert, J (1993), A Yær in a Life The American Infantryman in Vidnam (Novato, CA: Presidio Press).

Eisenhart, R (1975), 'Y ou can't hack it little girl: a discussion of the covert psychological agenda of modern combat training', Jamal of Social Issues, 31, 13-23.

Elder, G (1988), 'The life course as developmental theory', ChildDedqpment, 69, 1-12.

Elder, G and Clipp, E (1989), 'Combat experience and emotional health: impairment and resilience in later life', Jaumal of Pessonality, 57, 311-41.

Fett, MJ, et al. (1984), TheMatalityRepat, 3 vols. (Australian Veterans Health Studies; Canberra: AGPS).

Galiani, Sebastian , Rossi, Martín A., and Schargrodsky, Ernesto (2011), 'Conscription and Crime: Evidence from the Argentine Draft Lottery', American Econamic Jaumal: Applied Econamics 3 (2), 119-36.

Glenn, R (2000), ReedingAthena's DaneCard MenAgainst Firein Viemam(Annapolis, MD : Naval Institute Press).

Graziano, W, Jensen-Campbell, L, and Hair, E (1996), 'Perceiving interpersonal conflict and reacting to it: the case for agreeableness', Joumal of Pesanalityand Soial Psydhdogy, 70, 82035.

Graziano, W, et al. (2007), 'Agreeableness, empathy and helping: a person $\times$ situation perspective', Jaumal of Pessonalityand Social Psydhdogy, 93, 583-99. 
G renet, Julien, Hart, Robert A., and Roberts, J. Elizabeth (2011), 'Above and beyond the call. Long-term real earnings effects of British male military conscription in the post-war years', Labarr Econamis, 18, 194-204.

G rossman, D (1995), On Killing ThePsychdogical Cost of Lemingto Kill in War and Sociey (Boston: Little, Brown).

Ham, P (2007), Vienam TheAustralian War(Sydney: Harper Collins).

Hearst, Norman, Newman, Thomas B, and Hulley, Stephen B (1986), 'D elayed Effects of the Military D raft on Mortality', TheNewEngandJaumal of Meeidine, 314 (10), 620-24.

Hennessy, B (1997), TheShamp End TheTrauma of a War in Vienam(St Leonards, NSW: Allen \& Unwin).

Houdepohl, A, Parrott, D, and Zeichner, A (2010), 'Heterosexual men's anger in response to male homosexuality: effects of erotic and non-erotic depictions of male-male intimacy and sexual prejudice', Jamal of Hamosexuality, 57, 1022-38.

Imbens, Guido and van der Klaauw, Wilbert (1995), 'Evaluating the Cost of Conscription in the Netherlands', Jaumal of Businessand EconomicStatistics, 13 (2), 207-15.

International Institute for Strategic Studies (2012), TheMilitaryBalance(Routledge).

Jackson, J, et al. (2012), 'Military training and personality trait development: does the military make the man, or does the man make the military', Psychdogical Saience, 23, 270-77.

Keane, Michael P. (2010), 'Structural vs. Atheoretic Approaches to Econometrics', Jaumal of Econamtrics, 156, 3-20.

Knudsen, Eric I., et al. (2006), 'Economic, neurobiological, and behavioral perspectives on building America's future workforce', PNAS, 103 (27), 10155-62.

Lindo, Jason M and Stoecker, Charles (2012), Drawn into Vidence Evidence on 'What Makes a Criminal' fromtheV ienamDraft Latteies(NBER Working Paper No. 17818).

--- (forthcoming), 'D rawn into Violence: Evidence on 'What Makes a Criminal' from the Vietnam D raft Lotteries', EconamicInquiry.

Longley, K (2008), Gunts TheAmericanCombat SddierinVienam(Armonk, NY: M.E. Sharpe).

Marshall, SLA (1978), Men Against Fire ThePrddem of BattleCommand in FutureWar (G loucester, MA: Peter Smith).

Martin, R, Watson, D, and Wan, C (2000), 'A three-factor model of trait anger: dimensions of affect, behaviour, and cognition', Jamal of Pessnality, 65, 869-97.

McNeill, I (1984), The Team Australian Amy Adkisess in Vienam (Canberra: Australian War Memorial).

Miller, J and Lynam, D (2001), 'Structural models of personality and their relation to antisocial behavior: a meta-analytic review', Crimindogy, 39, 765-98. 
Morris, M (1996), 'By force of arms: rape, war and military culture', DukeLawJaumal, 45, 651781.

Mount, M, Ilies, R, and Johnson, E (2006), 'Relationship of personality traits and counterproductive work behaviors: the mediating effects of job satisfaction', Pescond Psydhoogy, 59, 591-622.

Nicol, A, Charbonneau, D, and Boies, K (2007), 'Right-wing authoritarianism and social dominance orientation in a Canadian military sample', MilitaryPsychdogy, 57, 401-21.

O 'Brien, M (1995), Conscipts and Regulars with the Seeeth Battalion in Vienam(St Leonards, NSW: Allen \& Unwin).

Oi, Walter Y (1967), 'The Economic Cost of the D raft', AmmicanEconmicReien, 57 (2), 39-62.

Ozer, D and Benet-Martinez, V (2006), 'Personality and the prediction of consequential outcomes', Annual Reiewof Psydhdogy, 57, 401-21.

Paloyo, Alfredo (2010), Compulsary Military Servicein Gemany Reisited (Bochum: Ruhr Economic Papers \#206).

Paloyo, Alfredo R., Vance, Colin , and Vorell, Matthias (2010), Local Deeminants of Cinme Do MilitaryBases Matter? (Ruhr-Universität Bochum: Ruhr Economic Papers \#211).

Q uigley, N (Signalman) (unpublished), 'Assorted Papers - 3rd Training Battalion', (Australian War Memorial).

Rintoul, S (1987), Ashes of Vienam Australian V dices(Richmond, VIC: Heinemann).

Roberts, B, Wood, D, and Caspi, A (2008), 'The development of personality traits in adulthood', in OP John, RW Robins, and LA Pervin (eds.), Handbook of Pesconality: Thery and Resarch (3rd edn.; New York, NY: Guildford Press), 375-98.

Rohlfs, Chris (2010), 'D oes Combat Exposure Make Y ou a More Violent or Criminal Person? Evidence From the Vietnam D raft', TheJarmal of Human Resarces, 45 (2), 271-300.

Sampson, R and Laub, J (1996), 'Socioeconomic achievement in the life course of disadvantaged men: military service as a turning point, circa 1940-1965', American Soidogial Reien, 61, $347-67$.

Siminski, Peter (forthcoming), 'Employment Effects of Army Service and Veterans' Compensation: Evidence from the Australian Vietnam-Era Conscription Lotteries', Reiewof Economics and Statistics

Siminski, Peter and Ville, Simon (2011), 'Long-Run Mortality Effects of Vietnam-Era Army Service: Evidence from Australia's Conscription Lotteries', American Economic Reient Papes \& Proeeding, 101 (3), 345-49.

--- (2012), 'I Was Only Nineteen, 45 Years Ago: What Can we Learn from Australia's Conscription Lotteries?', EconomicReoud, 88 (282), 351-71.

Simpson, N (Sgt) (unpublished), 'Unpublished Memoir', (Australian War Memorial). 
Training Information Bulletin 13 (1966), Marksmanship in the Australian Amy (Canberra: D irectorate of Military Training.).

Training Information Report (unpublished-a), 'Training Information Reports, 1969-70, HQ AFV', (Australian War Memorial).

--- (unpublished-b), 'Training Information Reports, 1970-71, HQ AFV', (Australian War Memorial).

Ville, Simon and Siminski, Peter (2011), 'A Fair and Equitable Method of Recruitment? Conscription by Ballot into the Australian Army during the Vietnam War', Australian EconomicHistary Reiew 51 (3), 277-96.

Westheider, J (2007), TheVienamWar(Westport, CT: Greenwood Press).

Wilkowski, B, Robinson, M, and Meier, B (2006), 'Agreeableness and the prolonged spatial processing of antisocial and prosocial information', Jarmal of Research in Pescolity, 40, 1152-68.

Wilson, EJ, Horsley, KW, and van der Hoek, R (2005), Australian National ServiceVienamV terans MatalityandCancer InidaneStudy2005 (Canberra: D epartment of Veterans' Affairs). 